University of Louisville

ThinkIR: The University of Louisville's Institutional Repository

$12-2011$

Ridge preservation comparing the clinical and histologic healing

of a demineralized particulate bone allograft vs. mineralized

particulate cancellous allograft using barrier membrane.

Veneta Kotevska

University of Louisville

Follow this and additional works at: https://ir.library.louisville.edu/etd

Recommended Citation

Kotevska, Veneta, "Ridge preservation comparing the clinical and histologic healing of a demineralized particulate bone allograft vs. mineralized particulate cancellous allograft using barrier membrane." (2011). Electronic Theses and Dissertations. Paper 774.

https://doi.org/10.18297/etd/774

This Master's Thesis is brought to you for free and open access by ThinkIR: The University of Louisville's Institutional Repository. It has been accepted for inclusion in Electronic Theses and Dissertations by an authorized administrator of ThinkIR: The University of Louisville's Institutional Repository. This title appears here courtesy of the author, who has retained all other copyrights. For more information, please contact thinkir@louisville.edu. 


\title{
RIDGE PRESERVATION COMPARING THE CLINICAL AND HISTOLOGIC HEALING OF A DEMINERALIZED PARTICULATE BONE ALLOGRAFT VS. MINERALIZED PARTICULATE CANCELLOUS ALLOGRAFT USING BARRIER MEMBRANE
}

\author{
By \\ Veneta Kotevska \\ DDS, University of Colorado, 2007
}

\author{
A Thesis \\ Submitted to the Faculty of the \\ School of Dentistry of the University of Louisville \\ in Partial Fulfillment of the Requirements \\ for the Degree of
}

Master of Science
Program in Oral Biology
School of Dentistry University of Louisville
Louisville, Kentucky

December 2011 
RIDGE PRESERVATION COMPARING THE CLINICAL AND HISTOLOGIC HEALING OF A DEMINERALIZED PARTICULATE BONE ALLOGRAFT VS. MINERALIZED PARTICULATE CANCELLOUS ALLOGRAFT USING

BARRIER MEMBRANE

\author{
By
}

Veneta Kotevska

DDS, University of Colorado, 2007

A Thesis Approved on

October 11, 2011

By the following Thesis Committee:

Henry Greenwell, Thesis Director

Margaret Hill

Bryan T. Harris

Dean Morton 


\section{DEDICATION}

This manuscript is dedicated to my parents for their loving support and guidance through my life. They honed my abilities and displayed an invaluable work ethic and acceptance to my overseas academic pursuits. 


\section{ACKNOWLEDGEMENTS}

I would like to express my sincere gratitude to the following individuals:

Dr. Henry Greenwell, Program Director of Graduate Periodontics, an unwavering mentor from whom I benefited a steadfast pattern of academic excellence.

Dr. Margaret Hill, Assistant Program Director, for her help in developing a well meaning and kindly outward behavior while displaying compassionate healthcare.

Dr. Brian S. Shumway, Assistant Professor, thank you very much for all of your help. Your input into my thesis is greatly appreciated.

Dr. Dean Morton, Assistant Dean, thank you for being a part of my clinical training, for taking the time to read my thesis and take part in my defense. 


\begin{abstract}
RIDGE PRESERVATION COMPARING THE CLINICAL AND HISTOLOGIC

HEALING OF A DEMINERALIZED PARTICULATE BONE ALLOGRAFT VS.

MINERALIZED PARTICULATE CANCELLOUS ALLOGRAFT USING A PTFE

BARRIER

Veneta Kotevska, DDS
\end{abstract}

October 11 th, 2011

\begin{abstract}
Aim. Differences in the healing of demineralized and mineralized allografts have been reported but their significance has not been evaluated in ridge preservation studies. The primary aims of this study were to compare ridge preservation using a mineralized cancellous allograft to a demineralized cortical allograft plus a PTFE barrier using clinical and histologic data to assess the outcomes.

Methods. Twelve positive controls received an intrasocket mineralized cancellous particulate allograft $(500-800 \mu \mathrm{m}$, Cancellous group) while twelve test patients received an intrasocket demineralized particulate allograft (250 to $710 \mu \mathrm{m}$, Demineralized group). All sites included in the study were covered with a PTFE barrier. Only nonmolar sites were included. Following tooth extraction and 4 month re-entry, horizontal ridge dimensions were measured with a digital caliper and vertical ridge changes were measured from a stent. Each site was re-entered for implant placement at about 4
\end{abstract}


months. Prior to implant placement, a $2.7 \times 6 \mathrm{~mm}$ trephine core was obtained and preserved in formalin for histologic analysis.

Results. The mean horizontal ridge width at the crest for the Cancellous group decreased from $8.2 \pm 1.5 \mathrm{~mm}$ to $6.9 \pm 1.5 \mathrm{~mm}$ for a mean loss of $1.3 \pm 1.4 \mathrm{~mm}(\mathrm{p}<0.05)$ while the Demineralized group decreased from $9.1 \pm 1.4 \mathrm{~mm}$ to $6.7 \pm 1.6 \mathrm{~mm}$ for a mean loss of $2.5 \pm 1.7 \mathrm{~mm}(\mathrm{p}<0.05)$. There were no statistically significance differences between the two groups $(\mathrm{p}>0.05)$. The mean mid-buccal vertical change for the Cancellous group was gain of $0.6 \pm 2.3 \mathrm{~mm}(\mathrm{p}>0.05)$ vs. a loss of $0.8 \pm 0.8 \mathrm{~mm}$ for the Demineralized group ( $p>0.05$ ). There were no statistically significant differences between groups for vertical change $(p>0.05)$. Histologic analysis revealed that the Cancellous group had 38 $\pm 14 \%$ vital bone, $29 \pm 14 \%$ non-vital bone, $32 \pm 10 \%$ trabecular space, while the Demineralized group had $40 \pm 13 \%$ vital bone, $21 \pm 14 \%$ non-vital bone, and $39 \pm 11 \%$ trabecular space. There were no statistically significant differences between groups for vital and novital bone or for trabecular space $(p>0.05)$.

Conclusions. Both treatments were effective in the preservation of horizontal and vertical ridge dimensions at sites for future implant placement. The Demineralized group, however, healed with a high percentage of vital bone, despite previous reports to the contrary, and the percentage of vital bone was similar to the amount achieved by the Cancellous group. 


\section{TABLE OF CONTENTS}

\section{PAGE}

ACKNOWLEDGEMENTS .......................................................................... iv

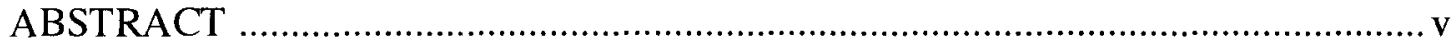

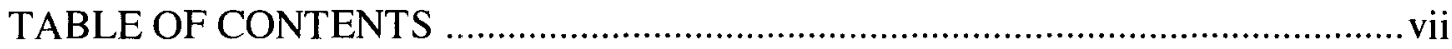

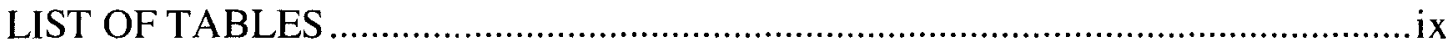

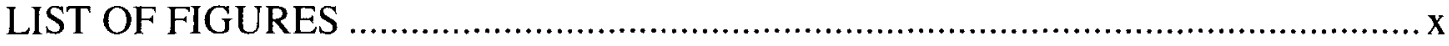

\section{CHAPTER}

\section{LITERATURE REVIEW}

Animal Extraction Socket Healing Sequence ................................... 1

Lindhe Studies ............................................................................ 3

Human Extraction Socket Healing Sequence ......................................6

Alveolar Ridge Resorption following Tooth Extraction ........................8

Clinical Studies of Ridge Preservation ............................................ 11

Histologic Evaluation of Ridge Preservation ..................................... 19

Extraction Alone Studies ........................................................... 20

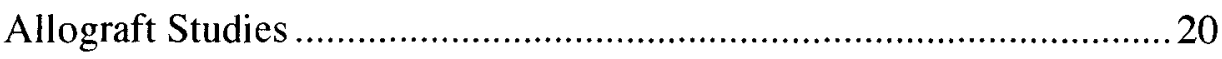

Xenograft Studies ........................................................................ 23

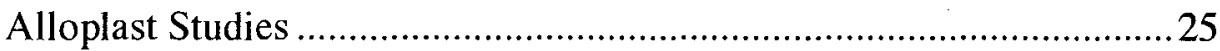

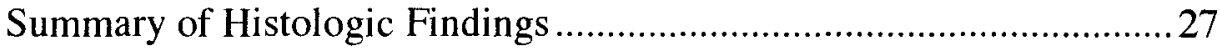

Summary of Literature Review ......................................................... 30 
II. MATERIALS AND METHODS

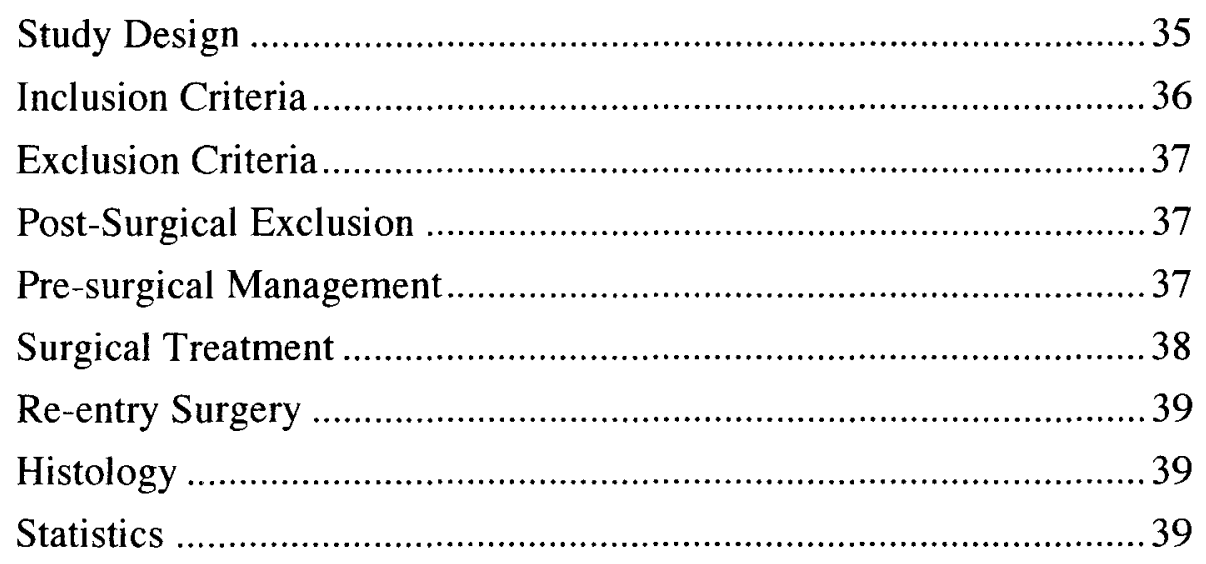

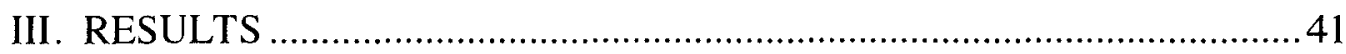

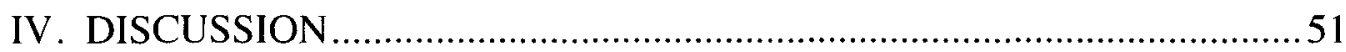

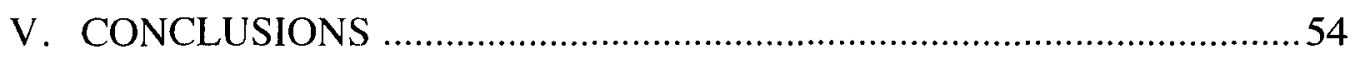

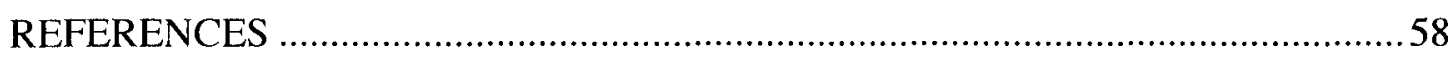

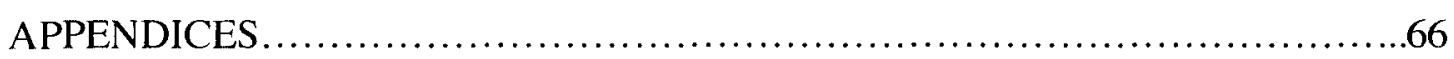

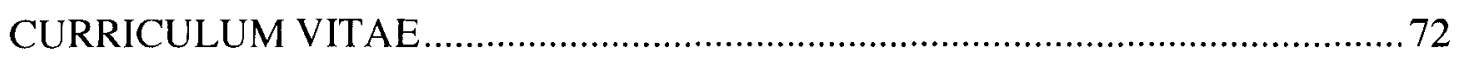




\section{LIST OF TABLES}

TABLE

PAGE

1. Animal extraction socket healing 31 days (Clafin 1936) .......................................

2. Animal extraction socket healing 180 days (Cardaropoli et al. 2003) ........................ 3

3. Human extraction socket healing 56 days (Araujo \& Lindhe 2005) ........................... 4

4. Human Extraction Socket Healing over 100 Days ................................................... 7

5. Events In Extraction Socket Healing ………........................................................ 8

6. Extraction Alone Studies Showing Change Alone ……........................................... 10

7. Extraction Alone Studies Showing Ridge Dimensions..........................11

8. Ridge Preservation Studies Showing Change Alone ............................................... 17

9. Ridge Preservation Studies Showing Ridge Dimensions............................18

10. Ridge Preservation Studies Showing Graft Type ................................................ 19

11. Comparison of Histologic Data on Extraction Alone Studies ..............................27

12. Comparison of Histologic Data on Ridge Preservation Studies ............................28

13. Root Dimensions at the Cervix by Tooth Types .................................................... 32

14. Horizontal Ridge Width at the Crest for U of L Studies .......................................... 34

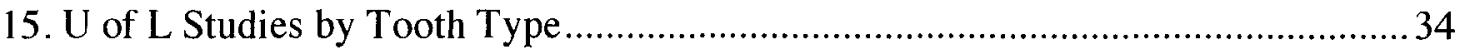

16. Clinical Indices for Cancellous and Cortical Sites .................................................44

17. Horizontal Ridge Width for Cancellous and Cortical Sites .................................... 45

18. Vertical Ridge Height Changes for Cancellous and Cortical Sites ............................46

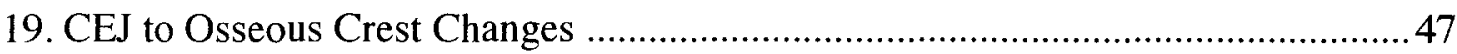

20. Histologic Data for Cancellous and Cortical Sites ...................................................48

21. Comparison of Histologic Data from U of L Ridge Preservation Studies ...............49

22. Comparison of Histologic Data from U of L Ridge Augmentation Studies ............50 


\section{LIST OF FIGURES}

\section{FIGURE}

PAGE

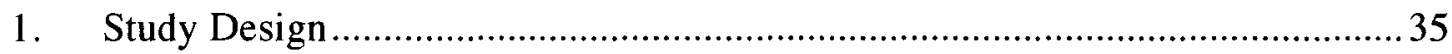

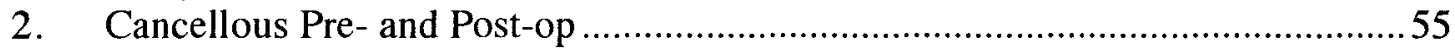

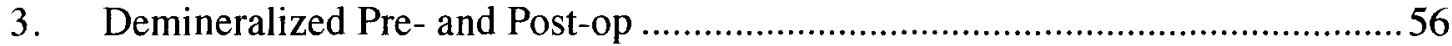

4. Representative Histologic Sections .............................................................5 57 


\section{CHAPTER I}

\section{LITERATURE REVIEW}

Dental implants have been widely accepted as a predictable treatment option for the replacement of missing teeth. The changes in alveolar dimensions after tooth extraction may greatly alter treatment decisions including the ability to place a dental implant for optimal esthetics and long-term success. Preservation or reconstruction of the extraction socket allows sufficient alveolar bone volume for implant placement. The demand for dental implants requires clinicians to be proficient at ridge preservation at the time of extraction to maintain post-extraction ridge width. The events following tooth extraction with or without a ridge preservation procedure has been studied in animals and humans.

\section{Animal Extraction Socket Healing Sequence}

Processes of hard tissue modeling and remodeling following tooth extraction were studied in the dog model. The earliest animal studies were completed in the 1930's. Claflin (1936) provided data on the histologic healing of extraction sockets up to 31 days

in dogs (Table 1). According to Claflin, healing began with clot formation at day 1, followed by infiltration with osteoclasts at day 3, then bone formation around 5-7 days. 
Epithelialization was complete over the clot around 7-9 days and complete socket fill occurred by 31 days. Despite complete socket fill, osteoclasts were still present, indicating that the healing was not complete at 31 days. Cardaropoli et al. (2003) extended the histologic analysis of healing process of extraction sockets in beagle dogs to 180 days (Table 2). Both studies showed that the initial process after extraction was the formation of a blood clot at day 1. Subsequent to that, neovascularization played a significant role up to 14 days when new bone was formed along the socket walls. By day 30, in accord with Clafin, the socket was completely filled with bone. According to Cardaropoli et al. (2003), the bone at 30 days was immature. It was not until day 90 that this woven or immature bone had remodeled to become lamellar, mature bone. By day 180 , the lamellar bone had undergone further remodeling and showed a slight decrease in mineralization due to the replacement of lamellar bone with bone marrow.

\section{Table 1}

Animal Extraction Socket Healing 31 Days (Clafin 1936)

\begin{tabular}{|l|l|}
\hline \multicolumn{1}{|c|}{ Time } & \multicolumn{1}{c|}{ Event } \\
\hline Day 1 & Blood clot formation \\
\hline Day 3 & $\begin{array}{l}\text { Osteoclast appear at crest of bone and fibroblast emerge } \\
\text { form socket walls }\end{array}$ \\
\hline Day 5 to 7 & First bone formation \\
\hline Day 7 to 9 & Epithelialization over clot completed \\
\hline Day 11 to 15 & New bone reaching the alveolar crest \\
\hline Day 28 to 31 & Socket filled with new bone, with osteoclasts still present \\
\hline
\end{tabular}


Table 2

Animal Extraction Socket Healing 180 Days (Cardaropoli et al. 2003)

\begin{tabular}{|l|l|}
\hline \multicolumn{1}{|c|}{ Time } & \multicolumn{1}{|c|}{ Event } \\
\hline Day 1 & $\begin{array}{l}\text { Blood clot formation comprised mostly of erythrocytes and } \\
\text { platelets }\end{array}$ \\
\hline Day 3 & Lysis of erythrocytes and clot being replaced by vascularized tissue \\
\hline Day 7 & New blood vessel formation \\
\hline Day 14 & New bone formation on socket walls \\
\hline Day 30 & Socket filled with new bone \\
\hline Day 90 & Woven bone replaced by lamellar bone \\
\hline Day 180 & Some lamellar bone being replaced by bone marrow spaces \\
\hline
\end{tabular}

\section{Lindhe Studies}

Araujo \& Lindhe (2005) examined histologic socket healing in the dog model using 12 sites in 12 mongrel dogs over a period of 8 weeks (Table 3). At 1 week, the central portion of the socket was occupied by coagulum. At the apical portion, islands of newly formed woven bone were noted adjacent to the bundle bone. By week 2, large amounts of newly formed bone were found in the apical and lateral portion of the socket. The surface of the woven bone was lined with densly packed osteoblasts and included a primitive bone marrow. By week 4 , the crestal bone, which was completely composed of bundle bone, was lost. Apical to the crestal region, a multitude of osteoclasts were observed on the outer surfaces of the buccal and lingual walls. By week 8 , the buccal wall was $2 \mathrm{~mm}$ apical to the lingual wall and considerably thinner. Between the buccal and lingual walls a mixture of woven and lamellar bone occupied the area. It can be 
concluded from this study that bundle bone begins to disappear as early as 2 weeks postextraction and the buccal wall is resorbed to greater extent than the lingual wall.

\section{Table 3}

Animal Extraction Socket Healing 56 Days (Araujo \& Lindhe 2005)

\begin{tabular}{|c|l|}
\hline Time & \multicolumn{1}{c|}{ Event } \\
\hline $\begin{array}{c}\text { Day } 7 \\
\text { (1 week) }\end{array}$ & $\begin{array}{l}\text { - internal portion of the socket occupied by coagulum } \\
\text { - apical portion showed islands of newly formed woven bone } \\
\text { adjacent to the bundle bone. }\end{array}$ \\
\hline $\begin{array}{c}\text { Day 14 } \\
\text { (2 weeks) }\end{array}$ & $\begin{array}{l}\text { - apical \& lateral portions showed large amounts of newly formed } \\
\text { woven bone } \\
\text { - surface of the woven bone was lined with densely packed } \\
\text { osteoblasts - primitive bone marrow. }\end{array}$ \\
\hline $\begin{array}{c}\text { Day 28 } \\
\text { (4 weeks) }\end{array}$ & $\begin{array}{l}\text { - at the crestal region, all bundle bone had been lost } \\
\text { - apical to the crestal region, a multitude of osteoclasts were } \\
\text { observed on the outer surfaces of the buccal and lingual walls. }\end{array}$ \\
\hline $\begin{array}{c}\text { Day 56 } \\
\text { (8 weeks) }\end{array}$ & $\begin{array}{l}\text { - lingual wall wider than buccal wall } \\
\text { - zone of mineralized tissue which consist of a mixture of woven } \\
\text { and lamellar bone had formed between the buccal and lingual } \\
\text { walls traveling in an oblique direction. }\end{array}$ \\
\hline
\end{tabular}

Araujo et al. (2005) studied the effects of immediate implant placement on the dimensional alterations of the alveolar ridge in beagle dogs, aside from studies that examined the socket healing with extraction alone. Sites that received an immediate implant to were compared to contralateral sites that received extraction alone over a period of 3 months. Extraction alone sites had a significant decrease in both height and width of the ridge. More importantly, the placement of an immediate implant failed to prevent the remodeling that occurred in the socket walls. Results were similar for both groups after 3 months of healing. This indicated that dimensional changes should be expected with immediate implant placement. 
In a 6-month study, Araujo \& Lindhe (2009) examined 5 mongrel dogs with bilateral extraction performed, compared full-thickness flap elevated on one side to the contralateral side that received a flapless technique. Results showed that there were marked alterations following extraction with or without flap elevation, especially in the coronal portion. There was $35 \%$ reduction in horizontal ridge dimension in the coronal portion. There were no significant differences between the two techniques.

The vascular supply around Branemark implants in beagle dogs was studied by Berglundh et al. (1994). It was observed that the blood vessels of the peri-implant mucosa were terminal branches of larger vessels from the periosteum at the implant site. The peri-implant supracrestal connective tissue, in comparison to a tooth, was almost devoid of vascular supply. Carmagnola et al. (2000) examined the histologic healing around implants placed in sites previously grafted with mineralized cortical bovine xenograft (Bio-Oss). Sixteen surgical defects were created in 4 beagle dogs. Results showed that osseointegration failed to occur at the implant surfaces and a well-defined connective tissue capsule was present between implant surfaces, in addition to a deep vertical bone defect frequently present along the lingual surface of the implant. Botticelli et al. (2004) examined the effects of three different surgically created defect configurations on bone healing around implants. They concluded that 4-wall defects completely resolved following implant placement. However, defects with a missing buccal plate had incomplete healing. Botticelli et al. (2005), in a follow-up study, examined the effects of implant surface, implant position and the presence of combined horizontal and vertical residual peri-implant defects on osseointegration in Labrador dogs. A substantial amount of bone fill and a high degree of osseointegration were noted around roughened implants 
compared to machined implants after 4 months of healing, regardless if the implant was placed in a submerged or non-submerged position. Results of this study suggest that implant surface characteristics play an important role in the amount of bone fill and level of osseointegration.

\section{Human Extraction Socket Healing Sequence}

The extraction socket healing in humans was evaluated by the following three studies. Amler (1960) studied socket healing histologically, in 75 human extraction sockets over a period of 50 days. Boyne (1966), in a study of 12 patients requiring extractions of all remaining maxillary teeth, examined the histological healing of one of the maxillary first premolar sockets over 23 days. Evian (1982) examined the histologic healing in 10 patients over a period of 16 weeks. Biopsies were taken at $4,6,8,10,12$, and 16 weeks post- extraction. These three studies showed that the human healing sequence followed a similar pattern to the dog models and is summarized in Table 4 below. 
Table 4

Human Extraction Socket Healing over 100 Days

\begin{tabular}{|l|l|}
\hline \multicolumn{1}{|c|}{ Time } & \multicolumn{1}{c|}{ Event } \\
\hline Day 1 & Blood clot formation \\
\hline Day $2-3$ & Granulation tissue appears \\
\hline Day 4 & Contraction of the blood clot begins \\
\hline Day $7-10$ & New bone formation \\
\hline Day 14 & $1 / 3$ socket filled \\
\hline Day 20 & Connective tissue replaces granulation tissue \\
\hline Day 38 & $2 / 3$ socket filled \\
\hline Day 100 & Radiopacity of socket was identical to surrounding bone \\
\hline
\end{tabular}

The formation of a blood clot occurred at day 1 for both dogs and humans in the healing sequence (Claflin 1936, Amler 1960). The following events were slightly different in humans and animals with regard to time. Around day 5 new bone formation was seen in dogs and along the lateral aspect of the socket by day 11 (Claflin 1936). New bone formation in humans was not detected until day 7-10 (Amler 1960). Extraction sockets were completely filled with new bone around day 30 in dogs (Claflin 1936). In contrast, Amler noted that only $2 / 3$ of the socket was filled at day 38 in humans, and Boyne (1966) reported that in humans only $1 / 3$ of the socket was filled by day 14 . Mature, lamellar bone was seen in dogs at day 90 (Cardaropoli et al. 2003), and this was not evident until day 100 in humans (Amler 1960). Table 5 compares the socket healing sequence for the dog and human models. 
Table 5

Events In Extraction Socket Healing

\begin{tabular}{|l|l|l|l|}
\hline Event & Time & Species & Study \\
\hline \multirow{3}{*}{ Blood Clot Formation } & 0 to 3 days & Dog & Claflin (1936) \\
\cline { 2 - 4 } & 0 to 1 day & Human & Amler et al. (1960) \\
\hline \multirow{3}{*}{ Fibroblast Proliferation } & 3 days & Dog & Claflin (1936) \\
\cline { 2 - 4 } & 2 to 35 days & Human & Amler et al. (1960) \\
\hline \multirow{3}{*}{ Osteoblast activity } & 3 to 31 days & Dog & Claflin (1936) \\
\hline \multirow{2}{*}{ First evidence of new bone } & 5 to 31 days & Dog & Claflin (1936) \\
\cline { 2 - 4 } & 7 days & Human & Amler et al. (1960) \\
\cline { 2 - 4 } & 10 days & Human & Boyne (1966) \\
\cline { 2 - 4 } & 28 days & Human & Evian et al. (1982) \\
\cline { 2 - 4 } Complete socket fill & 7 days & Dog & Clafin (1936) \\
\hline 1/3 socket fill & 30 days & Human & Amler (1960) \\
\hline $2 / 3$ socket fill & 14 days & Human & Clafin (1936) \\
\hline \multirow{2}{*}{ Mature bone present } & 38 days & Human & Amler (1960) \\
\hline & 90 days & Dog & Cardaropoli et al. (2003) \\
\cline { 2 - 4 } & 100 days & Human & Amler (1960) \\
\hline
\end{tabular}

\section{Alveolar Ridge Resorption Following Tooth Extraction}

The early loss of alveolar bone volume related to tooth extraction has been examined by many studies. The placement of endosseous dental implants was complicated because of alveolar ridge loss in height and width where an adequate amount of bone is needed to encompass the implant. Ridge position can have a significant effect on implant placement, esthetics, and the subsequent occlusal relationship of the restored 
implant. The residual ridge position is often lingualized compared to the original edentulous ridge. Most studies report that most of the ridge resorption occurs on the buccal aspect, resulting in a shift of the center of the ridge toward the palatal/lingual, (Lekovic et al. 1997, Lekovic et al. 1998, Iasella et al. 2003). Pietrokovski and Massler (1967) evaluated 149 dental casts with one tooth missing. Their results revealed that the buccal aspect of the alveolar ridge resorbs more than the lingual aspect independent of maxillary or mandibular arch location. The amount of facial resorption varied considerably between individual studies. Yilmaz et al. (1998) evaluated 5 patients (10 sites) with a single maxillary incisor extraction over a 12 month period and discovered a $17 \%$ decrease in ridge width. Schropp et al. (2003) found that most (2/3) resorption occurred in the first 3 months when evaluating study casts from 46 patients with a single premolar or molar extraction over a 12 month period. The amount of buccal-lingual ridge resorption after tooth extraction has been reported as $17-60 \%$ with the ridge height decreasing by $1 \mathrm{~mm}$, (Lekovic et al. 1997, Lekovic et al. 1998, Yilmaz et al. 1998, Camargo et al. 2000, Schropp et al. 2003, Iasella et al. 2003). These changes in ridge dimension must be taken into account whenever future dental implant placement might be a potential treatment option. The greatest amount of bone loss occurs within the first 2 years after tooth removal (Ashman 2000). Loss of alveolar ridge width and height can complicate placement of an endosseous dental implant since there must be adequate bone to completely surround the dental implant. Whether the residual ridge position is lingualized compared to the original edentulous ridge, or it has shifted toward the lingual, is an important consideration. Barone et al. (2008) evaluated 40 patients (40 sites) in a non-molar extraction study that was followed for 7 months. He noted a 
decrease of $41.7 \%$ in ridge width. The amount of buccal-lingual ridge resorption after tooth extraction has been reported as $17-63 \%$ with the ridge height decreasing by $1 \mathrm{~mm}$ (Lekovic et al. 1997, Lekovic et al. 1998, Yilmaz et al. 1998, Camargo et al. 2000, Schropp et al. 2003, Iasella et al. 2003, Barone et al. 2008). Data from these studies indicated that change in ridge width following tooth extraction varied substantially. Table 6 consists of studies that examined the mean change in the horizontal and vertical ridge dimensions following tooth extraction alone. These resorptive changes in ridge dimension may preclude future implant placement, or require additional surgical treatment to allow placement of functional, esthetic implants if ridge preservation is not performed at the time of extraction. Table 7 reports the ridge dimensions for the studies and percent change in ridge width.

Table 6

Extraction Alone Studies Showing Dimensional Change

\begin{tabular}{|l|c|l|l|l|}
\hline \multicolumn{5}{|l}{ Extraction Alone Studies } \\
\hline Study & $\begin{array}{l}\text { Reentry } \\
\text { Time } \\
\text { (months) }\end{array}$ & $\begin{array}{l}\text { Mean } \\
\text { Horizontal } \\
\text { Change mm }\end{array}$ & $\begin{array}{l}\text { Percent } \\
\text { Horizontal } \\
\text { Change }\end{array}$ & $\begin{array}{l}\text { Mean Vertical } \\
\text { Change mm }\end{array}$ \\
\hline Lekovic et al. 1997 & 6 & $-4.43 \pm 0.52$ & $-62.9 \%$ & $-0.88 \pm 0.26$ \\
\hline Lekovic et al. 1998 & 6 & $-4.59 \pm 0.23$ & $-61.3 \%$ & $-1.50 \pm 0.21$ \\
\hline Yilmaz et al. 1998* & 12 & $-0.75 \pm 0.59$ & $-17.0 \%$ & $-1.35 \pm 1.05$ \\
\hline Camargo et al. 2000 & 6 & $-3.06 \pm 2.41$ & $-40.8 \%$ & $-1.00 \pm 2.25$ \\
\hline Iasella et al. 2002 & $4-6$ & $-2.63 \pm 2.29$ & $-28.6 \%$ & $-0.90 \pm 1.60$ \\
\hline Schropp et al. 2003* & 12 & $-6.1 \pm 3.00$ & $-50.8 \%$ & $-0.20 \pm 1.60$ \\
\hline Barone et al. 2008 & 7 & $-4.5 \pm 0.8$ & $-41.7 \%$ & $-3.60 \pm 1.50$ \\
\hline Mean & $\mathbf{7 . 6} \pm \mathbf{3 . 2}$ & $\mathbf{- 3 . 7 \pm 1 . 7}$ & $-43 \pm 17$ & $-1.2 \pm 1.1$ \\
\hline
\end{tabular}

$*=$ measured from study casts 
Table 7

Extraction Alone Studies Showing Horizontal Ridge Dimensions

\begin{tabular}{|l|c|c|c|c|c|}
\hline Study & $\begin{array}{l}\text { Reentry } \\
\text { Time } \\
\text { (months) }\end{array}$ & $\begin{array}{l}\text { Mean } \\
\text { Initial } \\
\text { Horiz }\end{array}$ & $\begin{array}{l}\text { Mean Fin } \\
\text { Horiz }\end{array}$ & $\begin{array}{l}\text { Mean Horiz } \\
\text { Change }\end{array}$ & \% change \\
\hline Lekovic et al. 1997 & 6 & 7.0 & 2.6 & -4.4 & -63 \\
\hline Lekovic et al. 1998 & 6 & 7.5 & 2.9 & -4.6 & -61 \\
\hline Yilmaz et al. 1998* & 12 & 4.7 & 3.9 & -0.8 & -17 \\
\hline Camargo et al. 2000 & 6 & 7.5 & 4.4 & -3.1 & -41 \\
\hline Iasella et al. 2002 & $4-6$ & 9.1 & 6.4 & -2.6 & -29 \\
\hline $\begin{array}{l}\text { Schropp et al. } \\
\text { 2003* }\end{array}$ & 12 & 12.0 & 5.9 & -6.1 & -51 \\
\hline Barone et al. 2008 & 7 & 10.8 & 6.3 & -4.5 & -42 \\
\hline Mean & $\mathbf{7 . 6} \pm \mathbf{3 . 2}$ & $\mathbf{8 . 4} \pm \mathbf{2 . 5}$ & $\mathbf{4 . 6} \pm \mathbf{1 . 6}$ & $\mathbf{- 3 . 7 \pm 1 . 7}$ & $\mathbf{- 4 3} \pm \mathbf{1 7}$ \\
\hline
\end{tabular}

* measured from study casts

\section{Clinical Studies of Ridge Preservation}

The aim of the ridge preservation procedure is to prevent alveolar ridge atrophy and maintain adequate dimensions of bone in order to facilitate implant placement in prosthetically driven positions. It has been documented that without this procedure substantial ridge resorption is likely to occur. Ashman (2000) noted that when an extraction takes place and ridge preservation is not utilized the site of extraction could lose $40 \%$ to $60 \%$ of bone dimension within 2 to 3 years and subsequent loss of $0.25 \%$ to $0.5 \%$ annually. Iasella (2003) reported as much as $4 \mathrm{~mm}$ loss of ridge width in extraction alone sites within 4 to 6 months.

A crucial role in preserving osseous walls, thereby improving the chances of osseous graft success is the use of an atraumatic tooth extraction technique. Garg (2001) discussed 5 steps he considered necessary for an atraumatic extraction: 1) do not reflect 
the interdental papilla, especially in the esthetic zone; 2) focus on the actual process of tooth removal; 3) use elevators and forceps properly to reduce bony involvement and preserve bone contours; 4) section the tooth to help prevent bone loss; and 5) remove any soft tissue fragments or pathology. Horowitz (2005) added that use of a periotome is an important adjunct to atraumatic extractions. He stated that using periotomes to sever the periodontal ligament fibers allows the extraction to be performed with significantly less trauma. The greater the number of bony walls present following extraction, the more likely the osseous graft will be successful.

Comparison studies have shown that intrasocket ridge preservation prevents most, but not all ridge resorption (Tables $8-10$ ). Several ridge preservation studies have used barrier membranes in attempt to improve quality and quantity of bone fill in extraction sites. Both resorbable and non-resorbable barrier membranes have been used; some studies used membranes alone, others used membranes in conjunction with intrasocket grafting materials. Lekovic et al. (1997) compared extraction alone to use of a nonresorbable barrier membrane alone (Gore-Tex®) and Lekovic et al. (1998) compared extraction alone to use of a resorbable barrier membrane alone (Resolut $\AA$ ). In both studies, only non-molar teeth were included. The teeth were atraumatically extracted, the membrane was placed and primary closure was obtained. Reentry was performed 6months post-extraction. The results showed that both the non-resorbable (Gore-Tex®) and resorbable $($ Resolut $(\mathrm{R})$ barrier membranes provided comparable results. There was mean vertical resorption of $0.35 \mathrm{~mm}$ and a mean horizontal resorption of $1.53 \mathrm{~mm} \mathrm{(20 \% )}$. Results from Lekovic et al. $(1997,1998)$ reveal that the mean horizontal bone loss in the non-resorbable group (Gore-Tex ${ }^{\circledR}$ ) was $1.73 \mathrm{~mm}$, which was greater than the mean of 
$1.32 \mathrm{~mm}$ found in the resorbable membrane (Resolut $\left.{ }^{\circledR}\right)$ group. The extraction alone control group lost a mean of $4.5 \mathrm{~mm}$. The non-resorbable membrane sites had a mean reduction of $3.70 \mathrm{~mm}$ of horizontal width ( 2.5 fold) when compared to sites treated with extraction alone while the resorbable membrane sites had a mean reduction of $3.27 \mathrm{~mm}$ of having width loss ( 3.5 fold). These two studies show that there is not much difference between the use of a resorbable vs. a non-resorbable membrane for ridge preservation. Membrane use did, however, greatly decrease the amount of horizontal and vertical bone resorption when compared to extraction alone. Fotek et al. (2009) extracted 18 nonmolar teeth and grafted the socket with a mineralized bone allograft (Puros). In this 4month study, 9 sockets were covered with a acellular dermal matrix (ADM) and the other 9 with polytetrafluoroethylene (PTFE) membrane. In the ADM group, there was 27.89\% vital bone, $13.93 \%$ non-vital bone, and $59.19 \%$ trabecular space. There was $32.63 \%$ vital bone, $14.73 \%$ non-vital bone, and $52.64 \%$ trabecular space in the PTFE group. There appears to be no difference in the ulitilization of ADM or PTFE as a barrier in terms of histologic evidence. Camargo et al. (2000), in a 32 site ridge preservation study of

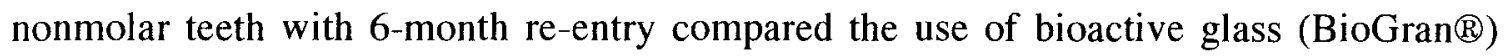
and calcium sulfate (Capset $\left.{ }^{\circledR}\right)$ to extraction alone. The mixture of bioactive glass and calcium sulfate resulted in a mean loss of ridge width of $3.48 \mathrm{~mm}$. The extraction alone resulted in a mean loss of ridge width of $3.06 \mathrm{~mm}$ which was less than the grafted sites. The extraction alone group showed a greater loss in ridge height $(1.0 \mathrm{~mm})$ over 6 months than the experimental group $(0.4 \mathrm{~mm})$. The results of the study concluded that the use of bioactive glass with calcium sulfate in preserving ridge width is not as effective as other techniques using traditional membrane barriers. Iasella et al. (2003) in a 4 to 6-month 
reentry study used 24 nonmolar sites and compared the use of freeze-dried bone allograft (FDBA) with a resorable membrane (Biomend Extend $®)$ to extraction alone. After four to six months of healing, the sites grafted with FDBA gained $1.3 \mathrm{~mm}$ in ridge height and lost only $1.2 \mathrm{~mm}$ in ridge width, in comparison to the extraction alone group, which had twice the amount of ridge width loss $(2.6 \mathrm{~mm})$, and $0.9 \mathrm{~mm}$ of ridge height loss.

Barone et al. (2008), compared corticocancellous porcine bone (MP3®) plus a collagen membrane $\left(\right.$ Evolution $\left.{ }^{\circledR}\right)$ to extraction alone in 40 non-molar sockets with a 7 month re-entry. He reported that the corticocancellous porcine bone and collagen membrane group had a mean loss of ridge width and height of $2.0 \mathrm{~mm}$ and $0.7 \mathrm{~mm}$, respectively. For the extraction alone group, he reported a mean loss of ridge width and height of $4.3 \mathrm{~mm}$ and $3.6 \mathrm{~mm}$, respectively. In a 10 patient case series, Cardaropoli \& Cardaropoli (2008) also studied corticocancellous porcine bone and a collagen membrane over 4 months. He reported a mean loss of $1.8 \mathrm{~mm}$ in ridge width after 4 months.

In addition to the extraction alone comparison studies, others have evaluated the effects of various graft materials used to preserve ridge dimensions. Nemcovsky and Serfaty (1996), in a 12-month, 23-patient, 23-socket study using non-resorbable hydroxyapatite (HA) crystals, showed a loss of ridge width of $0.6 \mathrm{~mm}$ and a loss of ridge height of $1.4 \mathrm{~mm}$ over 1 year. Simon et al. (2000) in a 4-month reentry study using particulate demineralized freeze-dried bone allograft (DFDBA) as an intrasocket and a buccal overlay graft along with a barrier membrane (Resolut XT®), reported an initial ridge width of $6.2 \pm 0.2 \mathrm{~mm}$ increasing to $7.3 \pm 0.2 \mathrm{~mm}$ for a gain of $1.1 \mathrm{~mm}$. Zubillaga et al. (2003), in a 10-patient, 11-socket study compared the use of demineralized bone matrix paste (Regenafil@) and a resorbable barrier membrane (Resolut $\left.{ }^{\circledR}\right)$ with or without 
fixation at four months. They reported that the mean change in ridge dimensions was a loss of $1.8 \mathrm{~mm}$ width, and a gain of $1 \mathrm{~mm}$ height. Vance et al. (2004), in a 4-month nonmolar reentry study using 24 extraction sockets compared the use of anorganic bovine bone matrix (BioOss $\left.{ }^{\circledR}\right)$ with a membrane to DFDBA plus mixture of calcium sulfate and carboxymethylcellulose (CalMatrix $\left.{ }^{\circledR}\right)$. They demonstrated that both groups had a mean loss of $0.5 \mathrm{~mm}$ ridge width. The BioOss ${ }^{\circledR}$ group showed a gain in mean ridge height of $0.7 \mathrm{~mm}$, while the CalMatrix ${ }^{\circledR}$ group showed a mean loss of $0.3 \mathrm{~mm}$. Adams et al. (2005) compared two different ridge preservation techniques in nonmolar sites in a 4 month re-entry study. An intrasocket cortical FDBA graft alone was compared to an intrasocket plus a buccal overlay (extrasocket) cortical FDBA graft. The intrasocket alone group had a mean ridge width loss of $2 \mathrm{~mm}$ and no change in ridge height. In contrast, the overlay group showed a mean ridge width loss of $1.4 \mathrm{~mm}$ and a gain of $2.2 \mathrm{~mm}$ of ridge height. Brkovic et al. (2008) in a single case report evaluated an alveolar ridge preservation technique involving placement of a cone of beta-tri-calcium phosphate (TCP) combined with type I collagen (RTR Cone $(\mathrm{R})$ without the use of a barrier or flap. Nine months after tooth extraction, they reported no reduction in ridge height and no change in ridge width. Neiva et al. (2008) in a 24 patient study over 4 months compared an anorganic bovine-derived hydroxyapatite matrix combined with a synthetic P-15 Putty (PepGen P-15 Putty®) and a bioabsorbable collagen wound dressing (CollaPlug®) to a bioabsorbable wound dressing alone. Neiva reported a loss of $1.31 \mathrm{~mm}$ in ridge width and a gain of $0.15 \mathrm{~mm}$ in ridge height for the Putty P15 group. For the bioabsorbable collagen wound dressing alone, a loss of $1.43 \mathrm{~mm}$ for ridge width and a loss of $0.56 \mathrm{~mm}$ in ridge height was reported (Tables 8,9 ). 
Previous studies have indicated, that even with the use of ridge preservation techniques to decrease the extent of bone resorption after an extraction, some loss of vertical and horizontal dimensions is likely to occur. The risk of decreased horizontal dimension significantly increases without ridge preservation being performed after an extraction. Over a $4-6$ month period, a $30-60 \%$ change $(2.7$ to $6.1 \mathrm{~mm})$ in horizontal dimension can be anticipated (Lekovic et al. 1997, Lekovic et al. 1998, Iasella et al. 2003, Schropp et al. 2003, Barone et al. 2008), ultimately, complicating and/or delaying implant placement 
Table 8

Ridge Preservation Studies Showing Change Alone

\begin{tabular}{|c|c|c|c|c|c|}
\hline Study & $\begin{array}{c}\text { Reentry } \\
\text { Time } \\
\text { months }\end{array}$ & Treatment & $\begin{array}{c}\text { Mean } \\
\text { Horizontal } \\
\text { Change } \\
\text { mm } \\
\end{array}$ & $\begin{array}{c}\text { Percent } \\
\text { Horizontal } \\
\text { Change }\end{array}$ & $\begin{array}{c}\text { Mean } \\
\text { Vertical } \\
\text { Change } \\
\text { mm } \\
\end{array}$ \\
\hline $\begin{array}{l}\text { Nemcovsky \& } \\
\text { Serfaty } 1996\end{array}$ & 12 & $\begin{array}{l}\text { Nonresorbable } \\
\text { HA crystals }\end{array}$ & $-0.6 \pm 0.66$ & N/A $\ddagger$ & $-1.4 \pm 0.50$ \\
\hline Lekovic et al. 1997 & 6 & ePTFE & $-1.7 \pm 0.56$ & $-23.3 \%$ & $-0.3 \pm 0.26$ \\
\hline Lekovic et al. 1998 & 6 & Resolut & $-1.3 \pm 0.21$ & $-17.6 \%$ & $-0.4 \pm 0.20$ \\
\hline Yilmaz et al. 1998 & 6 & $\begin{array}{l}\text { PerioGlas } \\
\text { cones }\end{array}$ & $+0.2 \pm 0.52$ & $+3.6 \%$ & $-0.1 \pm 0.87$ \\
\hline Camargo et al. 2000 & 6 & $\begin{array}{l}\text { BioGran } \\
\text { Capset }\end{array}$ & $-3.5 \pm 2.68$ & $-44.3 \%$ & $-0.4 \pm 3.18$ \\
\hline Simon et al. 2000 & 4 & $\begin{array}{l}\text { DFDBA/ } \\
\text { Resolut XT( }\end{array}$ & $+1.1 \pm \mathrm{NG}^{*}$ & $+18 \%$ & $-1.4 \pm N^{*}$ \\
\hline Iasella et al. 2003 & 4 & $\begin{array}{l}\text { FDBA/ } \\
\text { BioMend } \\
\end{array}$ & $-1.2 \pm 0.93$ & $-13.0 \%$ & $+1.3 \pm 2.00$ \\
\hline Zubillaga et al. 2003 & 4 & Regenafil & $-1.8 \pm \mathrm{NG}^{*}$ & $-16.8 \%$ & $+1.0 \pm \mathrm{NG}^{*}$ \\
\hline Vance et al. 2004 & 4 & $\begin{array}{l}\text { BioOss/ } \\
\text { BioGide }\end{array}$ & $-0.5 \pm 0.8$ & $-5.2 \%$ & $+0.7 \pm 0.4$ \\
\hline Vance et al. 2004 & 4 & $\begin{array}{l}\text { CalMatrix/ } \\
\text { Capset }\end{array}$ & $-0.5 \pm 0.8$ & $-5.6 \%$ & $-0.3 \pm 0.6$ \\
\hline Barone et al. 2008 & 7 & $\begin{array}{l}\text { xenograft, } \\
\text { collagen mem }\end{array}$ & $-2.0 \pm 0.9$ & $-23.6 \%$ & $-0.7 \pm 1.4$ \\
\hline Brkovic et al. 2008 & 9 & $\mathrm{~B}-\mathrm{TCP}+$ coll & $0.0 \pm 0.0$ & $0.0 \%$ & 0.0 \\
\hline Cardaropoli et al. 08 & 4 & $\begin{array}{l}\text { xenograft/coll } \\
\text { membrane }\end{array}$ & $-1.9 \pm 1.7$ & $-16.1 \%$ & NA \\
\hline Neiva et al. 2008 & 4 & P15/Collaplug & $-1.3 \pm 0.9$ & NA & $+0.2 \pm 1.8$ \\
\hline Neiva et al. 2008 & 4 & Collaplug & $-1.4 \pm 1.1$ & NA & $-0.6 \pm 1.0$ \\
\hline Fotek et al. 2009 & 4 & FDBA/ADM & -0.44 & NA & -1.11 \\
\hline Fotek et al. 2009 & 4 & FDBA/PTFE & -0.39 & NA & -0.25 \\
\hline Mean \pm sd & & & $-2.0 \pm 1.1$ & $-12 \pm 16$ & $-0.1 \pm 0.8$ \\
\hline
\end{tabular}

* NG $=$ not given in article

$\ddagger=$ no baseline measurements reported, unable to determine percentage 
Table 9

Ridge Preservation Studies Showing Horizontal Ridge Dimensions

\begin{tabular}{|c|c|c|c|c|c|}
\hline Study & $\begin{array}{c}\text { Reentry } \\
\text { Time } \\
\text { (months) }\end{array}$ & $\begin{array}{l}\text { Mean } \\
\text { Initial } \\
\text { Horiz }\end{array}$ & $\begin{array}{c}\text { Mean Fin } \\
\text { Horiz }\end{array}$ & $\begin{array}{c}\text { Mean Horiz } \\
\text { Change }\end{array}$ & $\%$ change \\
\hline $\begin{array}{l}\text { Nemcovsky \& } \\
\text { Serfaty } 1996\end{array}$ & 12 & & & -0.6 & \\
\hline Lekovic et al. 1997 & 6 & 7.3 & 5.6 & -1.7 & -23 \\
\hline Lekovic et al. 1998 & 6 & 7.4 & 6.1 & -1.3 & -18 \\
\hline Yilmaz et al. 1998 & 6 & 5.5 & 5.7 & +0.2 & +4 \\
\hline Camargo et al. 2000 & 6 & 7.9 & 4.4 & -3.5 & -44 \\
\hline Simon et al. 2000 & 4 & 6.2 & 7.3 & +1.1 & +18 \\
\hline Iasella et al. 2003 & 4 & 9.2 & 8.0 & -1.2 & -13 \\
\hline Zubillaga et al. 2003 & 4 & 10.7 & 8.9 & -1.8 & -17 \\
\hline Vance et al. 2004 & 4 & 8.9 & 8.4 & -0.5 & -6 \\
\hline Vance et al. 2004 & 4 & 9.7 & 9.2 & -0.5 & -5 \\
\hline Barone et al. 2008 & 7 & 10.6 & 8.1 & -2.5 & -24 \\
\hline Brkovic et al. 2008 & 9 & 12.0 & 12.0 & 0 & 0 \\
\hline Cardaropoli et al. 08 & 4 & 11.8 & 9.9 & -1.9 & -16 \\
\hline Neiva et al. 2008 & 4 & & & -1.3 & \\
\hline Neiva et al. 2008 & 4 & & & -1.4 & \\
\hline Fotek et al. 2009 & 4 & & & -0.4 & \\
\hline Fotek et al. 2009 & 4 & & & -0.3 & \\
\hline Mean & $5.8 \pm 2.6$ & $8.9 \pm 2.1$ & $7.8 \pm 2.1$ & $-2.0 \pm 1.1$ & $-12 \pm 16$ \\
\hline
\end{tabular}


Table 10

\section{Ridge Preservation Studies Showing Graft Type}

\begin{tabular}{|l|c|c|l|l|l|l|}
\hline $\begin{array}{l}\text { Graft } \\
\text { Type }\end{array}$ & $\begin{array}{l}\# \\
\text { studies }\end{array}$ & $\begin{array}{l}\text { Initial } \\
\text { Horiz }\end{array}$ & $\begin{array}{l}\text { Final } \\
\text { Horiz }\end{array}$ & $\begin{array}{l}\text { Change } \\
\text { Horiz }\end{array}$ & $\begin{array}{l}\% \\
\text { Change }\end{array}$ & $\begin{array}{l}\text { Change } \\
\text { Vertical }\end{array}$ \\
\hline Allograft & 6 & $8.8 \pm 1.9$ & $8.1 \pm 0.7$ & $-0.5 \pm 1.0$ & $-5 \pm 15$ & $0.1 \pm 1.0$ \\
\hline Xenograft & 4 & $10.7 \pm 1.1$ & $9.1 \pm 0.9$ & $-1.6 \pm 0.9$ & $-15 \pm 9$ & $0.1 \pm 0.7$ \\
\hline Alloplast & 4 & $8.5 \pm 3.3$ & $7.4 \pm 4.1$ & $-1.0 \pm 1.7$ & $-14 \pm 27$ & $-0.5 \pm 0.6$ \\
\hline Membrane alone & 2 & $7.4 \pm 0.1$ & $5.8 \pm 0.4$ & $-1.5 \pm 0.3$ & $-20 \pm 4$ & $-0.4 \pm 0.1$ \\
\hline Filler & & & & -1.4 & & $0.4 \pm 1.3$ \\
\hline
\end{tabular}

Horiz $=$ Horizontal

\section{Histologic Evaluation of Ridge Preservation}

The ideal bone grafting material will rapidly turnover, produce vital bone that fills the socket and, at the same time, maintain ridge dimensions. Histologic evaluation of bone quality is an important factor in the determining the appropriate material to use for a ridge preservation procedure. Bone quality also plays an important role in the process of implant placement. A bone quality index has been described by Lekholm \& Zarb (1985) which includes Type I bone being homogenous compact bone, Type II being a thick layer of compact bone surrounding a core of dense trabecular bone, Type III being a thin layer of cortical bone surrounding dense trabecular bone of favorable strength and Type IV being a thin layer of cortical bone surrounding a low-density trabecular bone. Type I 
bone is preferred for implant placement since it has the highest density of cortical bone and Type IV is the least preferred due to its very low density.

\section{Extraction Alone Studies}

The percentage of vital bone relative to trabecular space at 4-8 months, in an extraction socket, ranges from $26-54 \%$ while there was $46-67 \%$ trabecular space (Iasella et al. 2003, Froum et al. 2002, Serino et al. 2003, Barone et al. 2008, Table 11). Cardaropoli et al. (2003), in a 6 month canine study, reported only $15 \%$ vital bone and $85 \%$ trabecular space over 6 months. Pelegrine et al. (2010) in a 6 month study reported $43 \%$ vital bone and $57 \%$ trabecular space. Heberer et al. (2011) reported $44 \%$ vital bone and $56 \%$ trabecular space over 4 months of healing. It has been suggested that the large amount of trabecular space is due to the lack of load.

\section{Allograft Studies}

Mineralized particulate freeze-dried bone allograft (FDBA) and demineralized particulate freeze-dried bone allograft (DFDBA) are the primary two forms of allografts available commercially. FDBA provides an osteoconductive scaffold while DFDBA may provide osteoinductive proteins in addition to the osteoconductive scaffold (Mellonig et al.1981, Mellonig 1991). The osteoinductive properties of DFDBA have been attributed to the presence of bone morphogenetic proteins (BMPs). Urist (1965) identified BMPs, which were recognized to have osteoinductive potential. Urist \& Strates (1971) isolated BMPs from human cortical bone. BMPs were placed in ectopic sites in athymic mice, 
which then initiated bone formation. The demineralization process of allograft preparation releases BMP and allows osteoinduction to occur. Age and health status are factors that could affect osteoinductive potential. Commercial DFDBA from different bone banks exhibited wide variation in osteoinductive capabilities (Schwartz et al. 1996, $1998,2000)$. There was an age-dependent decrease in new bone induction for donors over the age of 50 .

Studies of demineralized freeze-dried bone allograft (DFDBA) used in ridge preservation procedures have reported conflicting results in regard to bone turnover. Histologic evaluations have shown a significant amount of non-vital DFDBA particles still present in core samples (Smukler et al. 1999, Froum et al. 2002). Becker et al. (1998) reported that several histologic samples showed DFDBA particles were encapsulated in dense connective tissue with no evidence of either osteoblastic or osteoclastic activity. This finding suggests that DFDBA may interfere with normal socket healing ultimately affecting bone to implant contact (Becker et al. 1994, 1996, 1998). In contrast, other studies have found that DFDBA particles fully resorb in some cases leaving only vital bone (Vance et al. 2004). In many cases, DFDBA has residual graft particles surrounded by intimately apposed woven and lamellar bone with distinct cement lines and a lack of fibrous encapsulation. Osteoblasts lined endosteal spaces and the new bone marrow exhibited a mild degree of fibrosis without signs of an inflammatory reaction (Brugnami et al. 1996, 1999, Smukler et al. 1999). Vance et al. (2004) examined 12 sockets grafted with a combination of DFDBA and an alloplastic putty consisting of calcium sulfate and carboxymethylcellulose (CalMatrix ${ }^{\circledR}$ ) over 4 months. Histologic analysis showed $61 \%$ vital bone, $3 \%$ non-vital bone, and $36 \%$ 
trabecular space. In previous studies, the percentage of vital bone present after utilizing DFDBA in ridge preservation ranged from 35 to $60 \%$ while only about $3-14 \%$ non-vital residual graft particles were present (Table 12). It must be noted that the failure to use an occlusive barrier membrane may be the cause of more residual graft particles and fibrous encapsulation in graft sites (Becker et al. 1996, 1998).

Freeze-dried bone allograft (FDBA), for a ridge preservation procedure showed a histologic result of $28 \%$ vital bone, $37 \%$ non-vital bone and $35 \%$ trabecular space over 4 6 months (Iasella et al. 2003). The residual FDBA particles were often surrounded by vital woven or lamellar bone, or were encapsulated in fibrous connective tissue. The residual graft material was higher than the amount with DFDBA, which may be due to the shorter healing period of $4-6$ months vs. up to 48 months for DFDBA. Wang \& Sao (2008) grafted five patients with solvent preserved mineralized particulate cancellous allograft (Puros $\left.{ }^{\circledR}\right)$. After 5 to 6 months they reported 69\% vital bone, $3.8 \%$ residual graft particles and 27\% trabecular space. Beck \& Mealey (2010) in one group of 19 sockets grafted with non-freeze-dried cancellous mineralized human bone allograft (Puros), reports after 3 month of healing, $45.8 \%$ vial bone, $14.6 \%$ non-vital bone and $39.6 \%$ trabecular space. In the second group of 14 sockets grafted with the same allograft (Puros) after 6 month of healing, he reported $45 \%$ vital bone, $13.5 \%$ non-vita bone and $41.3 \%$ trabecular space. Comparison of the two grafting materials is difficult since the healing periods were different for each of the studies. 


\section{Xenograft Studies}

Xenografts, mostly anorganic bovine bone, have also been utilized in ridge preservation procedures with similar results to allografts (Table 12). The particles showed evidence of osteoconductivity based on osseous ingrowth and close integration with newly formed bone (Artzi \& Nemcovsky 1998, Artzi et al. 2001, Froum et al. 2004, Table 12). Vance et al. (2004) showed that BioOss ${ }^{\circledR}$ had $26 \%$ vital bone with $16 \%$ nonvital bone and 58\% trabecular space after 4 months of healing. Zitzmann et al. (1997, 2001) reported similar results, in a 6-month study of 6 sockets grafted with BioOss $®$, $27 \%$ vital bone, $30 \%$ non-vital bone, and $43 \%$ trabecular space. Neiva et al. (2008), in a 24 patient study, compared a putty-form anorganic bovine-derived hydroxyapatite matrix combined with a synthetic cell-binding peptide P-15 (Putty P15) to a bioabsorbable collagen membrane to a bioabsorbable collagen dressing alone. He reported that the Putty P15 had 29.92\% vital bone, $65.25 \%$ bone marrow and $6.25 \%$ non-viable bone. The bioabsorbable group was reported to have $36.54 \%$ vital bone and $62.67 \%$ bone marrow. Nevins et al. (2009), in a 4 to 6 month study, grafted 8 socket with a mineralized collagen substitute (Bio-Oss Collagen) combined with platelet-derived growth factor-BB without a barrier. All treatment sites achieved adequate bone for the placement of standard size implants. There was $20 \%$ vital bone, $13.3 \%$ non-vital bone, and $66 \%$ trabecular space after 4 to 6 months of healing. Artzi et al. (2000) and Froum et al. (2004) found that xenografts produced a greater percentage of vital bone. Artzi et al. (2000), in a 9-month study, grafted 15 sockets in 15 patients using BioOss ${ }^{\circledR}$ and reported $46 \%$ vital bone, $31 \%$ non-vital bone, and $23 \%$ trabecular space. Froum et al. (2004), in a 6 to 8 month study, 
grafted 8 sockets with a nonresorbable anorganic bovine bone substitute (OsteoGraf R/N$300 囚), 4$ of which were combined with an ePTFE barrier, and the other 4 with Alloderm $\mathbb{R}(\mathrm{ADM})$ as a barrier. In the OsteoGraf/ePTFE group, there was $18 \%$ vital bone, $21 \%$ non-vital bone, and $61 \%$ trabecular space. The OsteoGraf/ADM $®$ group resulted in $42 \%$ vital bone, $13 \%$ non-vital bone, and $45 \%$ trabecular space. The two groups exhibited different amounts of vital bone, which was attributed to the choice of barrier material. The vascular channels in the Alloderm may have provided better revascularization compared to the ePTFE barrier. Araujo et al. (2008) grafted one quadrant of fresh extractions sockets in mongrel dogs with Bio-Oss Collagen ${ }^{\circledR}$ the other side was not grafted. After 3 months of healing, sites grafted with Bio-Oss Collagen® had $27 \%$ bone marrow, $58 \%$ vital bone, and $12 \%$ residual graft particles. The high percentage of vital bone was attributed to the incorporation of collagen into the BioOss $($. In a 40 patient study, Barone et al. (2008) compared grafting 20 sockets with OsteoBiol MP3®) and a collagen membrane (OsteoBiol Evolution $®)$ to extraction alone over 7 months. In the OsteoBiol MP3/Evolution group, they reported 36\% vital bone, $29 \%$ nonvital bone, and 37\% connective tissue. McAllister et al. (2010) after 3 month healing in 12 extraction sockets grafted with Bio-oss + PDGF reported $24 \%$ vital bone, $17 \%$ nonvital bone and 59\% trabecular space. Araujo \& Lindhe (2011) grafted two quadrants of extraction sockets in 5 beagle dogs with Bio-Oss Collagen and the other side was grafted with autologous bone. After 3 months of healing, sites grafted with Bio-Oss Collagen had $45 \%$ vital bone, $24 \%$ non-vital bone and $18 \%$ trabecular space. Heberer et al. (2011) compared grafting of 20 sockets with Bio-Oss Collagen to extraction alone over 4 months. In the Bio-Oss Collagen group, they reported $25 \%$ vital bone, $15 \%$ non-vital 
bone and $60 \%$ trabecular space. The percentage of vital bone present in sites grafted with xenografts appears to be strongly associated with the length of the healing period.

\section{Alloplast Studies}

Alloplastic materials such as bioactive glass, hydroxyapatite (HA) and calcium sulfate have been shown to produce vital bone formation from 25 to $60 \%$ (MacNeill et al. 1999, Froum et al. 2002, 2004 Guarnieri et al. 2004, and Mangano et al. 2008). These materials are osteoconductive and have no osteoinductive properties. Gaurnieri et al. (2004), in a 3 month study, utilized medical grade calcium sulfate hemihydrate in 10 sockets and reported 58\% vital bone and no residual graft particles in preserved sites. The sites were also devoid of any inflammatory cells and connective tissue. Calcium sulfate has a notably faster resorption time than xenografts and allografts. Hydroxyapatite, on the hand, has an extremely slow resorption rate as reported by Mangano et al. (2008) in a 20-year case report. Dense hydroxyapatite was used in post-extraction sites to maintain the alveolar height. Histologic analysis showed that vital bone represented $25.4 \%$ of the graft area, trabecular space $41.3 \%$ and $\mathrm{HA}$ residual particles $38.1 \%$. MacNeill et al. (1999) compared the histologic healing of 4 different alloplasts: hydroxyapatite (HA, OsteoGraf/P( ), bioactive glass \#1 (BioGran ${ }^{\circledR} \quad 300-360 \mu \mathrm{m}$ ), bioactive glass \#2 (PerioGlas ${ }^{\circledR}$ 90-710 $\mu \mathrm{m}$ ), and calcium sulfate (Capset $\left.{ }^{\circledR}\right)$ with autogenous bone, in osteotomy sites surgically created in the rabbit tibia over 28 days. All graft sites showed evidence of new bone formation at one month with the Capset ${ }^{\circledR}$ plus autogenous bone showing the greatest mean percentage of vital bone $(58.8 \%)$ and PerioGlas ${ }^{\circledR}$ showing the 
least $(40.4 \%)$, while the BioGran $\AA$ and OsteoGraf $/ P ®$ group both showed $41.8 \%$ vital bone. Froum et al. (2002) found similar results when treating 19 human sockets were with BioGran ${ }^{\circledR}$ over a 6-8 months period. Sockets treated with BioGran ${ }^{\circledR}$ resulted to $59 \%$ vital bone, $6 \%$ non-vital bone, and 35\% trabecular space. Froum et al (2004) treated 8 sockets with absorbable $\mathrm{HA}(\mathrm{OsteoGraf} \mathrm{R} / \mathrm{LD} \AA)$, 4 of which were combined with an ePTFE barrier, while the remaining 4 were treated with an Alloderm ${ }^{\circledR}(\mathrm{ADM})$ barrier. After 6-8 months of healing, the HA/ADM group showed $35 \%$ vital bone, $4 \%$ non-vital bone, and $62 \%$ trabecular space, while the HA/ePTFE group showed $28 \%$ vital bone, $12 \%$ non-vital bone, and $61 \%$ trabecular space (Table 12). Serino et al. (2003) treated 34 sockets, in a 6 month study, with a bioabsorbable polylactide/polyglycolic acid sponge (Fisiograft $₫$ ). Histologic analysis resulted in $67 \%$ vital bone and $33 \%$ trabecular space. In a 3 month study, Crespi et al. (2009) evaluated 45 sockets, 15 grafted with magnesium-enriched hydroxyapatite (MHA), 15 grafted with calcium sulfate (CS), while the remaining 15 were non-grafted sites. The MHA group resulted in $40 \%$ vital bone, $20.2 \%$ non-vital bone, and $41.3 \%$ trabecular space. In the CS group there was $45 \%$ vital bone, $13.9 \%$ non-vital bone, and $41.5 \%$ trabecular space. The CS group had a greater percentage of vital bone and less non-vital bone, indicating greater bone formation and faster resorption. In a single 9-month case report, Brkovic et al. (2008) evaluated betaTCP with type I collagen (RTR Cone ${ }^{\circledR}$, Septodont, Saint-Maur-des-Fosses, France) and reported $62.6 \%$ vital bone, $21.1 \%$ marrow and $16.3 \%$ residual B-TCP graft. This is the highest percentage of vital bone reported for the alloplasts. McAllister et al. (2010) in a 3 month study in the group of 12 sockets grafted with PDGF + TCP, reported $21 \%$ vital bone, $24 \%$ non-vital bone and $55 \%$ trabecular space. 


\section{Summary of Histologic Fndings}

The percentage of vital and nonvital bone as well as trabecular space varies considerably, when analyzing the histologic findings of studies of ridge preservation procedures performed using a variety of grafting materials, including allografts (DFDBA, FDBA), xenografts (anorganic bovine bone mineral), or alloplasts (hydroxyapatite, calcium sulfate, and polylactide/polyglycolic acid sponge). The percentage of vital bone ranged from $1-67 \%$, the percentage of non-vital bone ranged from $0-42 \%$, and the percentage of trabecular space ranged from $33-85 \%$.

Table 11

\section{Comparison of Histologic Data on Extraction Alone studies}

\begin{tabular}{|l|l|c|c|c|}
\hline \multicolumn{1}{|c|}{ Author/Yr } & Species & $\begin{array}{c}\text { Healing } \\
\text { Months }\end{array}$ & \% Vital Bone & $\begin{array}{c}\text { \% Trabecular } \\
\text { Space }\end{array}$ \\
\hline Froum et al. 2002 & Human & $6-8$ & 32.4 & 67.6 \\
\hline Iasella et al. 2003 & Human & $4-6$ & 54.0 & 46.0 \\
\hline Serino et al. 2003 & Human & 6 & 44.0 & 56.0 \\
\hline Barone et al. 2008 & Human & 7 & 26 & 59.0 \\
\hline Crespi et al. 2009 & Human & 3 & 33.0 & 65.0 \\
\hline Mean \pm sd & & $\mathbf{6 \pm 2}$ & $\mathbf{3 8 \pm 1 1}$ & $\mathbf{5 6} \pm \mathbf{1 3}$ \\
\hline
\end{tabular}


Table 12

Comparison of Histologic Data on Ridge Preservation studies

\begin{tabular}{|c|c|c|c|c|c|c|}
\hline Author/Yr & $\begin{array}{c}\text { Graft } \\
\text { Material }\end{array}$ & $\begin{array}{l}\text { Particle } \\
\text { Size }\end{array}$ & $\begin{array}{l}\text { Healing } \\
\text { Months }\end{array}$ & $\begin{array}{c}\% \text { Vital } \\
\text { Bone }\end{array}$ & $\begin{array}{c}\text { \% Non- } \\
\text { Vital } \\
\text { Bone } \\
\end{array}$ & $\begin{array}{c}\% \% \\
\begin{array}{c}\text { Trabecular } \\
\text { Space }\end{array} \\
\end{array}$ \\
\hline \multicolumn{7}{|l|}{ Allografts } \\
\hline $\begin{array}{l}\text { Froum et al. } \\
2002\end{array}$ & DFDBA & \begin{tabular}{|l|}
250 to \\
$500 \mu \mathrm{m}$ \\
\end{tabular} & $6-8$ & 34.7 & 13.5 & 51.8 \\
\hline $\begin{array}{l}\text { Iasella et al. } \\
2003\end{array}$ & FDBA & $\begin{array}{l}500-1000 \\
\mu \mathrm{m}\end{array}$ & $4-6$ & 30.1 & 34.7 & 35.2 \\
\hline $\begin{array}{l}\text { Vance et al. } \\
2004\end{array}$ & \begin{tabular}{|l|} 
DFDBA/putty \\
$($ CalMatrix ()
\end{tabular} & $\begin{array}{l}500-1000 \\
\mu \mathrm{m}\end{array}$ & 4 & 61.0 & 3.0 & 36.0 \\
\hline $\begin{array}{l}\text { Fotek et al. } \\
2009\end{array}$ & \begin{tabular}{|l|} 
Canc \\
Puros/ADM
\end{tabular} & $\begin{array}{l}250-1000 \\
\mu \mathrm{m}\end{array}$ & 4 & 28 & 14 & 58 \\
\hline $\begin{array}{l}\text { Fotek et al. } \\
2009\end{array}$ & \begin{tabular}{|l|} 
Canc \\
Puros/PTFE \\
\end{tabular} & \begin{tabular}{|l|}
$250-1000$ \\
$\mu \mathrm{m}$
\end{tabular} & 4 & 33 & 15 & 52 \\
\hline Mean \pm sd & & & & $41 \pm 17$ & $18 \pm 17$ & $38 \pm 13$ \\
\hline \multicolumn{7}{|l|}{ Xenografts } \\
\hline $\begin{array}{l}\text { Artzi et al. } \\
2000\end{array}$ & BioOss ${ }^{\circledR}$ & $\begin{array}{l}250-1000 \\
\mu \mathrm{m}\end{array}$ & 9 & 46.3 & 30.8 & 42.6 \\
\hline $\begin{array}{l}\text { Zitzmann et } \\
\text { al. } 2001\end{array}$ & BioOss ${ }^{\circledR}$ & $\begin{array}{l}250-1000 \\
\mu \mathrm{m}\end{array}$ & 6 & 26.9 & 30.5 & 42.6 \\
\hline $\begin{array}{l}\text { Froum et al. } \\
2004\end{array}$ & \begin{tabular}{|l|} 
OsteoGraf \\
R/N300 + \\
ADM \\
\end{tabular} & $\begin{array}{l}250-420 \\
\mu \mathrm{m}\end{array}$ & 7 & 42.0 & 13.0 & 45.0 \\
\hline $\begin{array}{l}\text { Froum et al. } \\
2004\end{array}$ & $\begin{array}{l}\text { OsteoGraf } \\
\text { R/N300 } \\
+ \text { ePTFE }\end{array}$ & $\begin{array}{l}250-420 \\
\mu \mathrm{m}\end{array}$ & 7 & 18.0 & 21.0 & 61.0 \\
\hline $\begin{array}{l}\text { Vance et al. } \\
2004\end{array}$ & BioOss® & $\begin{array}{l}250-500 \\
\mu \mathrm{m}\end{array}$ & 4 & 26.0 & 16.0 & 54.0 \\
\hline $\begin{array}{l}\text { Barone et } \\
\text { al. } 2008\end{array}$ & $\begin{array}{l}\text { OsteoBiol MP3 } \\
+ \text { OsteoBiol } \\
\text { Evolution }\end{array}$ & $\begin{array}{l}600-1000 \\
\mu \mathrm{m}\end{array}$ & 7 & 35.5 & 29.2 & 36.6 \\
\hline $\begin{array}{l}\text { Cardaropoli } \\
\text { et al. } 2008\end{array}$ & $\begin{array}{l}\text { OsteoBiol } \\
\text { GenOs }+ \\
\text { OsteoBiol } \\
\text { Evolution }\end{array}$ & $\begin{array}{l}250-1000 \\
\text { um }\end{array}$ & 4 & NR & 24.5 & NR \\
\hline $\begin{array}{l}\text { Neiva et al. } \\
2008\end{array}$ & $\begin{array}{l}\text { Putty P-15 + } \\
\text { collaPlug }\end{array}$ & $\begin{array}{l}250-420 \\
\mathrm{um}\end{array}$ & 4 & 29.9 & 6.3 & 65.3 \\
\hline Mean & & & $6 \pm 2$ & $31 \pm 9$ & $23 \pm 11$ & $47 \pm 14$ \\
\hline
\end{tabular}




\begin{tabular}{|c|c|c|c|c|c|c|}
\hline \multicolumn{7}{|l|}{ Alloplasts } \\
\hline $\begin{array}{l}\text { Froum et al. } \\
2002\end{array}$ & $\begin{array}{l}\text { Bioactive Glass } \\
\text { (BioGran }(\text { ) }\end{array}$ & $\begin{array}{l}300-355 \\
\mu \mathrm{m}\end{array}$ & $6-8$ & 59.5 & 5.5 & 35.0 \\
\hline $\begin{array}{l}\text { Froum et al. } \\
2004\end{array}$ & $\begin{array}{l}\text { HA (OsteoGraf } \\
\text { R/LD) + ADM }\end{array}$ & $\begin{array}{l}250-420 \\
\mu \mathrm{m}\end{array}$ & 4 & 35.0 & 4.0 & 62.0 \\
\hline $\begin{array}{l}\text { Froum et al. } \\
2004\end{array}$ & $\begin{array}{l}\text { HA (OsteoGraf } \\
\text { R/LD) + } \\
\text { ePTFE }\end{array}$ & $\begin{array}{l}250-420 \\
\mu \mathrm{m}\end{array}$ & 4 & 28.0 & 12.0 & 61.0 \\
\hline $\begin{array}{l}\text { Luczyszyn } \\
\text { et al. } 2005\end{array}$ & $\begin{array}{l}\text { HA } \\
\text { (Algipore }{ }^{\circledR} \text { ) } \\
+ \text { ADM }\end{array}$ & NA & 6 & 1.0 & 42.0 & 57.0 \\
\hline $\begin{array}{ll}\text { Brkovic } & \text { et } \\
\text { al. 2008 }\end{array}$ & $\begin{array}{l}\text { B-TCP, Type } 1 \\
\text { collagen }\end{array}$ & $\begin{array}{l}500- \\
1000 \mu \mathrm{m}\end{array}$ & 9 & 62.6 & 16.3 & 21.1 \\
\hline $\begin{array}{l}\text { Mangano et } \\
\text { al. } 2008\end{array}$ & dense $\mathrm{HA}$ & $\begin{array}{l}1 \text { to } 2 \\
\mu \mathrm{m}\end{array}$ & 240 & 25.4 & 38.1 & 41.3 \\
\hline $\begin{array}{l}\text { Crespi et al. } \\
2009\end{array}$ & $\begin{array}{l}\text { Magnesium } \\
\text { HA }\end{array}$ & & 3 & 40 & 20 & 41 \\
\hline Mean & & & $7 \pm 2$ & $36 \pm 21$ & $20 \pm 15$ & $46 \pm 15$ \\
\hline \multicolumn{7}{|c|}{ Membrane Alone } \\
\hline $\begin{array}{l}\text { Luczyszyn } \\
\text { et al. } 2005\end{array}$ & ADM & NA & 6 & 46.0 & 0.0 & 54.0 \\
\hline \multicolumn{7}{|c|}{ Collagen Filler Material } \\
\hline $\begin{array}{l}\text { Serino et al. } \\
2003\end{array}$ & $\begin{array}{l}\text { Polylactide/ } \\
\text { Polyglycolic } \\
\text { acid sponge } \\
\text { (Fisiograft } \circledast \text { ) }\end{array}$ & NA & 6 & 67.0 & 0.0 & 33.0 \\
\hline $\begin{array}{l}\text { Neiva et al. } \\
2008\end{array}$ & Collaplug & NA & 4 & 36.5 & 0.0 & 62.7 \\
\hline Mean & & & & $52 \pm 21$ & $\mathbf{0} \pm 0$ & $48 \pm 21$ \\
\hline
\end{tabular}

${ }^{*} \mathrm{NR}=$ not reported in article 


\section{Summary of Literature Review}

The events that occur following extraction alone have been studied in animal and human models. The healing sequence of an extraction socket begins with the formation of a blood clot around day 1 , followed by neovascularization around day 3 , and subsequent new bone formation starting at around 5-7 days (Clafin 1936, Cardaropoli et al. 2003, Amler 1960, Boyne 1966, Evian 1982). There are some slight differences in animals and humans in regards to healing. Complete socket fill was noted at day 30 in dogs (Clafin 1936), while only $2 / 3$ of the socket was filled in humans at day 38 (Amler 1960). Mature, lamellar bone was seen as early as 90 days in dogs (Cardaropoli et al. 2003), but this was not present until day 100 in humans (Amler 1960).

The results from studies of the histologic healing of the extraction sockets have shown that without any type of ridge preservation procedure the percentage of vital bone present after 4-8 months of healing ranged from $33-54 \%$ with $34-67 \%$ of trabecular space (lasella et al. 2003, Froum et al. 2002, Serino et al. 2003, Barone et al. 2008). Cardaropoli et al (2003) in the canine model reported only $15 \%$ vital bone and $85 \%$ trabecular space after 6 months of healing.

Histologic results vary within and between graft types. Studies using allografts (DFDBA, FDBA) for ridge preservation (Smukler et al. 1999, Froum et al. 2002, Vance et al. 2004, Iasella et al. 2003) have yielded variable results. Percentage of vital bone ranged from $30-61 \%$, non-vital bone ranged from $3-35 \%$, while percentage trabecular space ranged from $35-56 \%$. Variations in the results may be attributable to the range in time of re-entry from 4 to 240 months. Ridge preservation studies using xenografts (BioOss ${ }^{\circledR}$, OsteoGraf ${ }^{\circledR}$ ) showed similar results to allografts with a range of $18-46 \%$ of 
vital bone, $13-31 \%$ of non-vital bone, and $43-61 \%$ of trabecular space. The variation in results in studies using alloplasts $\left(\right.$ BioGran $\AA$, PerioGlas $\AA$, Algipore ${ }^{\circledR}$, hydroxyapatite, calcium sulfate, Fisograft ${ }^{\circledR}$, Collaplug $\left({ }^{\circledR}\right)$ differed significantly with re-entry times from 1 to 8 months. From these studies, a range of $1-67 \%$ vital bone, $0-42 \%$ non-vital bone, and 33-62.7\% trabecular space were reported. (Nevins et al. 2009), examined the use of a BioOss Collagen ${ }^{\circledR}$ and PDGF for ridge preservation and they reported $21 \%$ vital bone, $13 \%$ non-vital bone, and 66\% trabecular space. McAllister et al. (2010) after 3 month healing in 12 extraction sockets grafted with Bio-oss + PDGF reported $24 \%$ vital bone, $17 \%$ non-vital bone and 59\% trabecular space. Studies using Bio-Oss Collagen (Araujo \& Lindhe 2011 , Heberer et al. 2011) reported a range of $25-45 \%$ vital bone, $15-24 \%$ nonvital bone and $18-60 \%$ trabecular space.

Loss of alveolar ridge width following tooth extraction is a common reported sequelae. This loss of alveolar ridge width can significantly complicate and delay the time of implant placement. All sockets lose horizontal width irrespective of their initial width. Thus sockets that are initially narrow, such as incisors, will end up still narrower following healing. Therefore the tooth type may be one of main variables in determining the feasibility of placement of a dental implant and may be predictive of the final outcome. Table 13 summarizes the root dimensions at the cervix as categorized by tooth types. 
Table 13

Root Dimensions at the Cervix by Tooth Types (Ash-Wheeler $6^{\text {th }}$ Ed. 1984, Woelfel 1990)

\begin{tabular}{|c|c|c|c|c|}
\hline \multirow[t]{2}{*}{ Tooth Types } & \multicolumn{2}{|c|}{$\begin{array}{c}\text { Bucco-lingual/palatal } \\
\text { dimensions mm }\end{array}$} & \multicolumn{2}{|c|}{$\begin{array}{c}\text { Mesio-distal dimensions } \\
\mathrm{mm} \\
\end{array}$} \\
\hline & Ash-Wheeler & Woelfel & Ash-Wheeler & Woelfel \\
\hline $\begin{array}{l}\text { Mandibular incisors } \\
\text { Central } \\
\text { Lateral }\end{array}$ & $\begin{array}{l}5.3 \\
5.8 \\
\end{array}$ & $\begin{array}{l}5.4 \\
5.8 \\
\end{array}$ & $\begin{array}{l}3.5 \\
4.0 \\
\end{array}$ & $\begin{array}{l}3.5 \\
3.8 \\
\end{array}$ \\
\hline $\begin{array}{l}\text { Maxillary incisors } \\
\text { Central } \\
\text { Lateral } \\
\end{array}$ & $\begin{array}{l}6.0 \\
5.0 \\
\end{array}$ & $\begin{array}{l}6.4 \\
5.8 \\
\end{array}$ & $\begin{array}{l}7.0 \\
5.0 \\
\end{array}$ & $\begin{array}{l}6.4 \\
4.7 \\
\end{array}$ \\
\hline $\begin{array}{l}\text { Mandibular \& Maxillary } \\
\text { canines }\end{array}$ & 7.0 & $\begin{array}{l}\mathrm{Mx}: 7.6 \\
\mathrm{Mn}: 7.5\end{array}$ & 5.5 & $\begin{array}{l}\mathrm{Mx}: 5.6 \\
\mathrm{Mn}: 5.2 \\
\end{array}$ \\
\hline Mandibular $1^{\text {st }}$ premolars & 6.5 & 7.0 & 5.0 & 4.8 \\
\hline Mandibular $2^{\text {nd }}$ premolars & 7.0 & 7.3 & 5.0 & 5.0 \\
\hline $\begin{array}{l}\text { Maxillary premolars }\left(1^{\text {st }} \&\right. \\
\left.2^{\text {nd }}\right)\end{array}$ & 8.0 & $\begin{array}{l}1^{\text {st }}: 8.2 \\
2^{\text {nd }}: 8.1 \\
\end{array}$ & 5.0 & $\begin{array}{l}1^{\text {st: }}: 4.8 \\
2^{\text {nd: }}: 4.7\end{array}$ \\
\hline Mandibular $1^{\text {st }}$ molars & 9.0 & 10.7 & 9.0 & 7.9 \\
\hline Mandibular $2^{\text {nd }}$ molars & 9.0 & 10.7 & 8.0 & 7.6 \\
\hline Mandibular 3rd molars & 9.0 & 10.4 & 7.5 & 7.2 \\
\hline Maxillary $1^{\text {st }}$ molars & 10.0 & 9.0 & 8.0 & 9.2 \\
\hline Maxillary $2^{\text {nd }}$ molars & 10.0 & 8.8 & 7.0 & 9.1 \\
\hline Maxillary $3^{\text {rd }}$ molars & 9.5 & 8.9 & 6.5 & 9.2 \\
\hline
\end{tabular}

Different tooth types possess different bucco-lingual/palatal and mesio-distal dimensions (Table 13). In general, incisors are the smallest, while molars are the widest in dimension. As a result, ridge preservation becomes increasingly critical for the smaller tooth types, especially mandibular incisors, since even a small amount of horizontal ridge resorption can be detrimental.

The main goal of ridge preservation is to minimize the loss of alevolar ridge dimension following extraction. As was evident from the extraction alone studies 
reviewed (Lekovic et al. 1997, Lekovic et al. 1998, Yilmaz et al. 1998, Camargo et al. 2000, Iasella et al. 2003, Schropp et al. 2003), the change in ridge width following tooth extraction varies substantially, and this broad range (30-60\%) may have a profound influence on the future tooth replacement options available.

Despite the use of a bone graft to preserve alveolar ridge dimensions, most studies have reported a net loss in horizontal and/or vertical ridge dimensions. However, Simon et al. (2000) in a 4-month reentry study using particulate DFDBA as an intrasocket and a buccal overlay graft along with a barrier membrane (Resolut XTß), reported a mean net gain of approximately $1.1 \mathrm{~mm}$ of ridge width.

The University of Louisville has studied ridge preservation since 2003 (Iasella et al. 2003, Vance et al. 2004, Adams 2005, Siu 2007, Witonsky 2009, Sams 2010). Since that time horizontal ridge width change has ranged from -0.5 to $-2.0 \mathrm{~mm}$ with a mean of $1.1 \mathrm{~mm}$. The percent change has ranged from $-5 \%$ to $-21 \%$ with a mean of $-13 \%$. A small amount of ridge loss could be due to the small amount of time the flap was open, while a longer surgical procedure may lead to more bone loss (Table 14). Another factor in varying results is tooth type. According to the University of Louisville studies (Table 15), maxillary tooth types compared to the same mandibular tooth types had a greater percentage ridge width loss. Thus, results of a study could vary based on the distribution of teeth in the sample (Table 15). 


\section{Table 14}

\section{Horizontal Ridge Width at the Crest for U of L Studies}

Mean \pm sd in $\mathbf{m m}$

\begin{tabular}{|lllcc|}
\hline & Initial & Final & Change & \% Change \\
\hline Iasella 2003 FDBA & & & & \\
Vance 2004 Calmatrix & $9.2 \pm 1.2$ & $8.0 \pm 1.4$ & $-1.2 \pm 0.9$ & -13 \\
Vance 2004 BioGide/BioOss & $8.9 \pm 1.8$ & $8.4 \pm 1.5$ & $-0.5 \pm 0.7$ & -6 \\
Adams 2005 Intra FDBA & $9.7 \pm 1.1$ & $9.2 \pm 1.1$ & $-0.5 \pm 0.8$ & -5 \\
Adams 2005 Overlay FDBA & $9.4 \pm 1.2$ & $7.4 \pm 1.5$ & $-2.0 \pm 0.9^{*}$ & -21 \\
Siu 2007 Flap & $8.5 \pm 1.0$ & $7.1 \pm 1.2$ & $-1.4 \pm 1.0^{*}$ & -17 \\
Siu 2007 Flapless & $8.5 \pm 1.5$ & $7.5 \pm 1.5$ & $-1.0 \pm 1.1$ & -12 \\
Witonsky 2009 BioCol & $8.3 \pm 1.3$ & $7.0 \pm 1.9$ & $-1.3 \pm 1.0$ & -16 \\
Witonsky 2009 PTFE & $8.6 \pm 1.0$ & $7.3 \pm 1.0$ & $-1.3 \pm 0.9$ & -15 \\
Sams 2010 Cortical & $7.9 \pm 1.5$ & $6.8 \pm 1.4$ & $-1.1 \pm 1.1$ & -14 \\
Sams 2010 Cancellous & $8.6 \pm 2.0$ & $6.7 \pm 2.3$ & $-1.9 \pm 1.4$ & -23 \\
Kotevska 2011 Demineralized & $8.4 \pm 1.1$ & $6.3 \pm 1.6$ & $-2.0 \pm 1.6$ & -24 \\
Kotevska 2010 Cancellous & $9.1 \pm 1.4$ & $6.7 \pm 1.6$ & $-2.5 \pm 1.7^{*}$ & -26 \\
\hline Mean & $8.2 \pm 1.5$ & $6.9 \pm 1.5$ & $-1.3 \pm 1.4^{*}$ & -15 \\
\hline$*=p<0.05$ between initial and 4-month values & $\mathbf{8 . 7 \pm 0 . 5}$ & $\mathbf{7 . 3} \pm \mathbf{0 . 8}$ & $\mathbf{- 1 . 4} \pm \mathbf{0 . 6}$ & $\mathbf{- 1 6} \pm \mathbf{7}$ \\
\hline
\end{tabular}

$*=\mathrm{p}<0.05$ between initial and 4-month values

Table 15

U of L Studies by Tooth Type

Mean $\pm \mathrm{sd}$ in $\mathbf{m m}$

\begin{tabular}{|lccccc|}
\hline & n & Initial & Final & Change & \% Change \\
\hline Maxillary Incisor & 37 & $7.8 \pm 1.0$ & $5.9 \pm 1.3$ & $-1.9 \pm 1.2$ & $-24 \pm 14$ \\
Mandibular Incisor & 2 & $5.9 \pm 0.2$ & $5.1 \pm 0.0$ & $-0.9 \pm 0.2$ & $-15 \pm 3$ \\
Maxillary Canine & 6 & $8.9 \pm 0.8$ & $6.1 \pm 2.4$ & $-2.8 \pm 2.2$ & $-32 \pm 24$ \\
Mandibular Canine & 3 & $7.8 \pm 1.8$ & $7.0 \pm 2.5$ & $-0.8 \pm 1.7$ & $-9 \pm 23$ \\
Maxillary Premolar & 91 & $9.4 \pm 1.2$ & $8.1 \pm 1.3$ & $-1.3 \pm 1.1$ & $-14 \pm 11$ \\
Mandibular Premolar & 23 & $7.8 \pm 1.3$ & $7.5 \pm 1.3$ & $-0.4 \pm 1.0$ & $-4 \pm 13$ \\
\hline
\end{tabular}




\section{CHAPTER II}

\section{METHODS}

Study design. A total of 24 patients requiring extraction of a nonmolar tooth to be replaced by a dental implant participated in this 4-month randomized, controlled, single blinded clinical trial. Twelve positive control patients were randomly selected, using a coin toss, to receive a cancellous particulate 500-800 $\mu \mathrm{m}$ allograft plus a PTFE barrier membrane, while twelve test patients were selected to receive a demineralized particulate 250-710 $\mu \mathrm{m}$ allograft plus a PTFE barrier. Both groups received a full thickness papilla preservation flap on the buccal and lingual/palatal. All surgical procedures were completed by one operator under the direction of one mentor. The surgeon was trained in the procedures until considered proficient. All measurements were performed by a blinded examiner. The mentor performed the coin toss and verified the measurements taken by the blinded examiner. All patients signed an informed consent approved by the University of Louisville Institutional Review Board in July 2010. The study was conducted between January 13th, 2011 and July 1st, 2011 in the Graduate Periodontics clinic. At 4-months post-surgery, a trephine was used to obtain an osseous core from the grafted site prior to the osteotomy for implant placement. Trephine cores were sectioned and prepared for histologic analysis using hematoxylin and eosin staining. 
Figure 1
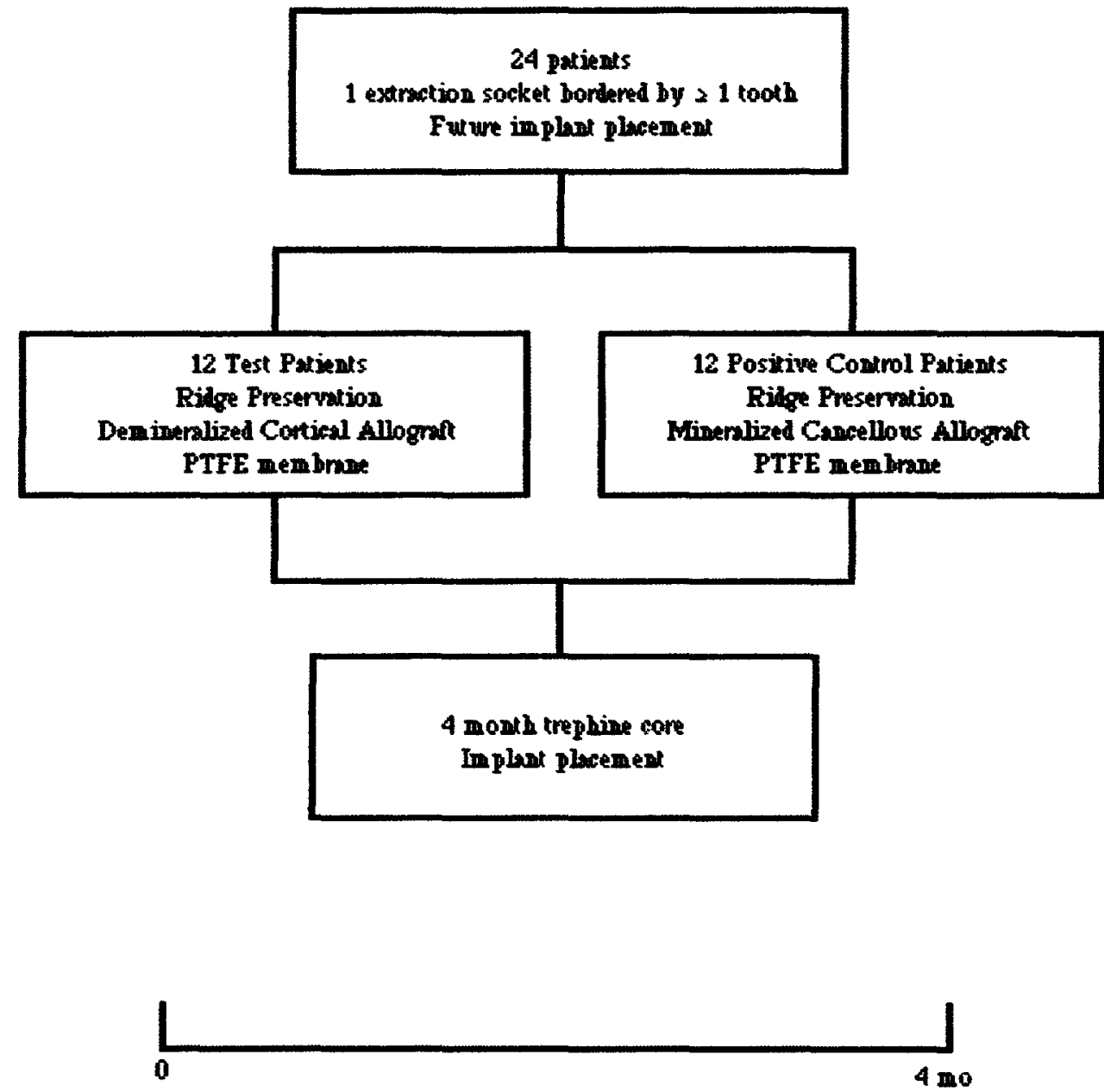

Vertical mesures from stent Horizontal measumes with caliper Robiogmph

Frobing metswes

Pertical measures from stent Horizontal measwes with caliper Trephine core Radiogaph Probing metsures

Inclusion Criteria. Patients were included in the study if they: 1) had at least one non-molar tooth requiring extraction that will be replaced by a dental implant; 2) had at least one site bordered by at least one tooth; 3) were at least 18 years old; and 4) signed an informed consent approved by the University of Louisville Human Studies Committee. 
Exclusion Criteria. Patients were excluded if any of the following were present: 1) debilitating systemic diseases, or diseases that affect the periodontium;2) molar teeth; 3) the patient had an allergy to any material or medication used in the study; 4) the patient required prophylactic antibiotics; 5) the patient had previous head and neck radiation therapy; 6) the patient received chemotherapy in the previous 12 months; or 7) if the patient was on long term NSAID or steroid therapy.

Post-Surgical Exclusion. Any site excluded after surgery was reported. Sites were excluded if there was: 1) loss of graft or barrier material; or 2) unanticipated healing complications that adversely affected treatment results.

Presurgical Management. Each patient received a diagnostic work-up including standardized periapical radiographs (Appendix D), study casts, clinical photographs, and a clinical examination to record attachment level, probing depth, recession, and mobility of teeth adjacent to the extracted sites. Customized Triad@ occlusal stents were fabricated on the study casts to serve as fixed reference guides for the measurements (Appendix F).

Presurgical preparation included detailed oral hygiene instructions. Baseline data was collected just before the surgical phase of the treatment. Baseline data included: 1) Plaque index (Silness and Löe 1964, Appendix A); 2) Gingival index (Loe 1967, Appendix B); 3) Bleeding on Probing Index (Tagge 1975, Appendix C); 4) Gingival margin levels measured from CEJ to the gingival margin; 5) Keratinized tissue measured from the gingival margin to the mucogingival junction; 6) Clinical attachment level measured from CEJ to the bottom of the clinical periodontal pocket; 7) Clinical tooth mobility measured by using the modified Miller's Index; 8) Horizontal ridge width 
measured using a digital caliper to the nearest $10^{-2} \mathrm{~mm}$ at the mid point of the alveolar crest and $5 \mathrm{~mm}$ apical to the crest, measured post-extraction and prior to implant placement; 9) Vertical change in the alveolar crest measured post-extraction from the stent to alveolar crest minus re-entry stent to alveolar crest values; 10) Radiographic examination using a customized stent constructed using Triad® light cured resin (Appendix F) and a Rinn-XCP on the patient model (Appendix D) to ensure standardization of the projection; and 11) Clinical photographs.

Surgical Treatment. Patients were anesthetized with $2 \%$ lidocaine containing epinephrine in both $1: 100,000$ and $1: 50,000$ concentrations. Full-thickness mucoperiosteal flaps were elevated on the buccal and palatal/ lingual using a papilla preservation technique. An acrylic stent was used to obtain vertical ridge height measurements relative to the stent.

A digital caliper was utilized to obtain horizontal ridge dimension at the midsocket crest and $5 \mathrm{~mm}$ apical to the crest. The positive control patients received a cancellous particulate $500-800 \mu \mathrm{m}$ graft and the test patients received an allograft composed of demineralized partculate $250-710 \mu \mathrm{m}$. Both groups were covered using a barrier membrane (PTFE). The flaps were replaced and sutured with 4-0 Cytoplast PTFE sutures (Osteogenics Biomedical Lubbock, TX). Subjects were given a post-surgical regimen of naproxen sodium (Geneva Pharmaceuticals, Inc. Broomfield, CO), $375 \mathrm{mg}$, every 12 hours for 1 week; doxycycline hyclate $50 \mathrm{mg}$ once daily (Warner Chilcott Inc. Morris Planes, New Jersey) for 2 weeks, and narcotic analgesics as needed. Postoperative care was given at 2, 4, 8, and 12 weeks. Photographs were taken at each postoperative appointment. 
Re-entry Surgery. At 4 months, a standardized radiograph was taken and all baseline measurements were repeated. Patients were anesthetized with $2 \%$ lidocaine containing epinephrine in both $1: 100,000$ and 1:50,000 concentrations. Full-thickness mucoperiosteal flaps were elevated on the buccal and palatal/lingual using a papilla preservation technique. An acrylic stent was used to obtain vertical ridge height measurements relative to the stent. A digital caliper was utilized to obtain horizontal ridge dimension at the mid-buccal crest and $5 \mathrm{~mm}$ apical to the crest.

At 4 months post-surgery, a $2.7 \times 6.0 \mathrm{~mm}$ trephine (H \& H Company Ontario, California) was used to remove a core from the grafted site prior to osteotomy for implant placement. The core was placed into $10 \%$ buffered formalin for histologic preservation. An osteotomy site was prepared and an endosseous dental implant was placed. The flaps were replaced and sutured with 4-0 silk sutures. Patients were again given naproxen 375 $\mathrm{mg}$, doxycycline hyclate $50 \mathrm{mg}$ and analgesics as needed.

Histology. Trephine cores $(2.7 \times 6 \mathrm{~mm})$ were decalcified and step serial sections were taken from each longitudinally sectioned core. The sections were stained with hematoxylin and eosin. Ten slides per patient were prepared with at least 4 sections per slide. All slides were evaluated and 6 of 10 representative slides were counted. The mean percentage of vital and non-vital bone and trabecular space was calculated for each patient by using an American Optical microscope at $150 \mathrm{X}$ with a $10 \mathrm{X} 10$ ocular grid.

Statistical Analysis. Means and standard deviations were calculated for all parameters. A paired t-test was used to evaluate the statistical significance of the differences between initial and final data. An unpaired t-test was used to evaluate statistical differences between the test and control groups. The sample size of 12 per 
group gave $83 \%$ statistical power to detect a difference of $1 \mathrm{~mm}$ between groups. Power calculations were based on data from previous studies. 


\section{CHAPTER III}

\section{RESULTS}

A total of 6 females and 6 males with a mean age of $51.4 \pm 15.0$, ranging from 32 to 77 , were enrolled in the Cancellous group while 7 females and 5 males with a mean age of $53.4 \pm 13.7$, ranging from 31 to 77 , were enrolled in the Demineralized group. All sites were bordered by two teeth. All patients completed the study. The Cancellous group consisted of 2 maxillary incisors, 5 maxillary premolars, and 5 mandibular premolars. The Demineralized group consisted of 2 maxillary incisors, 1 maxillary canine, 8 maxillary premolars and 1 mandibular premolar. There were no smokers enrolled in either group. Data from this study were derived from 24 patients all treated by one operator (VK).

Clinical Indices. Plaque index, gingival index and bleeding on probing had low initial values for both groups and the majority of values only changed slightly by the 4 month reentry (Table 16). The bleeding on probing for the Cancellous group decreased significantly from initial to final values, a decrease of $0.3(p<0.05$. Table 16).

Horizontal Ridge Width Changes. The Cancellous group presented with a mean crestal width of $8.2 \pm 1.5 \mathrm{~mm}$, which decreased to $6.9 \pm 1.5 \mathrm{~mm}$ at the 4 month reentry for a mean loss of $1.3 \pm 1.4 \mathrm{~mm}(\mathrm{p}<0.05$, Table 17). For the Demineralized group the mean initial width at the crest was $9.1 \pm 1.4 \mathrm{~mm}$, which decreased to $6.7 \pm 1.6$ $\mathrm{mm}$ for a mean loss of $2.4 \pm 1.7 \mathrm{~mm}(\mathrm{p}<0.05)$. The Cancellous group had a mean initial 
width $5 \mathrm{~mm}$ apical to the crest of $9.1 \pm 2.1 \mathrm{~mm}$, which decreased to $8.4 \pm 2.4 \mathrm{~mm}$ at month 4 for a mean loss of $0.7 \pm 1.3 \mathrm{~mm}(\mathrm{p}>0.05)$. The Demineralized group had a mean initial width $5 \mathrm{~mm}$ apical to the crest of $9.8 \pm 1.2 \mathrm{~mm}$, which decreased to $8.0 \pm 1.6$ $\mathrm{mm}$ for a mean loss of $1.8 \pm 1.6 \mathrm{~mm}(\mathrm{p}<0.05)$. There were no statistically significant differences between groups $(\mathrm{p}>0.05)$.

Vertical mid-Buccal Ridge Height Changes. The Cancellous group had a mean mid-buccal ridge height gain of $0.6 \pm 2.3 \mathrm{~mm}(\mathrm{p}>0.05$, Table 18), while the Demineralized group lost $0.8 \pm 0.8 \mathrm{~mm}(\mathrm{p}<0.05)$. There were no statistically significance differences between the Cancellous and Demineralized groups for the midbuccal change $(p>0.05)$.

Vertical mid-Lingual Ridge Height Changes. Mid-lingual ridge height in the Cancellous group had a mean gain of $0.0 \pm 0.9 \mathrm{~mm}(\mathrm{p}>0.05$, Table 18), while the Demineralized group had a mean loss of $0.7 \pm 1.1 \mathrm{~mm}(\mathrm{p}<0.05)$. There were no statistically significance differences between groups $(\mathrm{p}>0.05)$.

Vertical Mesial Ridge Height Changes. Vertical mesial ridge height for the Cancellous group had a mean loss of $0.4 \pm 1.0 \mathrm{~mm}(\mathrm{p}>0.05$, Table 18), while the Demineralized group had a mean loss of $0.7 \pm 1.1 \mathrm{~mm}(\mathrm{p}<0.05)$. There were no statistically significance differences between groups $(\mathrm{p}>0.05)$.

Vertical Distal Ridge Height Changes. Vertical distal ridge height for the Cancellous group showed a mean loss of $0.6 \pm 0.6 \mathrm{~mm}(\mathrm{p}<0.05$, Table 18), while the Demineralized group had a loss of $0.9 \pm 0.7 \mathrm{~mm}(\mathrm{p}<0.05)$. There were no statistically significance differences between groups $(p>0.05)$. 
CEJ to Osseous Crest Changes. The mesial and distal CEJ to osseous crest change for both the Cancellous and Demineralized groups was minimal from time 0 to 4 months ( $p>0.05$, Table 19). There were no statistically significant differences between groups for either mesial or distal sites $(\mathrm{p}>0.05)$.

Histologic evaluation. Cancellous sites healed with $38 \pm 14 \%$ vital bone, $29 \pm$ $14 \%$ non-vital bone, $32 \pm 10 \%$ trabecular space, while Demineralized sites healed with $40 \pm 13 \%$ vital bone, $21 \pm 14 \%$ non-vital bone, and $39 \pm 11 \%$ trabecular space. For vital bone, nonvital bone and trabecular space there were no statistically significant differences between the Cancellous and Demineralized groups $(\mathrm{p}<0.05$, Table 20). Histologic results from previous $U$ of $L$ ridge preservation studies (Table 21) and ridge augmentation studies (Table 22) are summarized to allow comparison of different grafting materials. 
Table 16

\section{Clinical Indices for Cancellous and Demineralized Sites}

Mean \pm sd in index units

\begin{tabular}{|ccccc|}
\hline & & Initial & Final & Change \\
\hline \hline Plaque & Cancellous & $0.2 \pm 0.3$ & $0.2 \pm 0.2$ & $0.0 \pm 0.3$ \\
Index & Demineralized & $0.2 \pm 0.3$ & $0.3 \pm 0.3$ & $-0.1 \pm 0.3$ \\
\hline Gingival & Cancellous & $0.8 \pm 0.3$ & $0.5 \pm 0.4$ & $-0.3 \pm 0.4$ \\
Index & Demineralized & $0.6 \pm 0.3$ & $0.4 \pm 0.4$ & $-0.2 \pm 0.4$ \\
\hline $\begin{array}{c}\text { Bleeding } \\
\text { on } \\
\text { Probing }\end{array}$ & Cancellous & $0.4 \pm 0.2$ & $0.1 \pm 0.2$ & $-0.3 \pm 0.2^{*}$ \\
$*=\mathrm{p}<0.05$ between initial and 4-month values & $0.3 \pm 0.2$ & $0.2 \pm 0.2$ & $-0.1 \pm 0.3$ \\
\hline
\end{tabular}


Table 17

Horizontal Ridge Width for Cancellous and Demineralized Sites

Mean \pm sd in $\mathbf{m m}$

\begin{tabular}{|lccccc|}
\hline & Initial & Final & Change & \% Change & Range \\
\hline & Initial & Final & Change & & Range \\
$\begin{array}{l}\text { Cancellous at Crest } \\
\text { Demineralized }\end{array}$ & $8.2 \pm 1.5$ & $6.9 \pm 1.5$ & $-1.3 \pm 1.4^{*}$ & $-15 \pm 17$ & -3.5 to 1.9 \\
at Crest & $9.1 \pm 1.4$ & $6.7 \pm 1.6$ & $-2.4 \pm 1.7^{*}$ & $-26 \pm 19$ & -6.2 to 0.5 \\
$\begin{array}{l}\text { Cancellous at } 5 \text { mm } \\
\text { Demineralized }\end{array}$ & $9.1 \pm 2.1$ & $8.4 \pm 2.4$ & $-0.7 \pm 1.3$ & $-8 \pm 13$ & -3.2 to 1.8 \\
at 5 mm & $9.8 \pm 1.2$ & $8.0 \pm 1.6$ & $-1.8 \pm 1.6^{*}$ & $-18 \pm 16$ & -5.3 to 0.4 \\
& & & & & \\
$*$
\end{tabular}


Table 18

Vertical Ridge Height Change for Cancellous and Demineralized Sites

Mean \pm sd in $\mathbf{m m}$

\begin{tabular}{|c|c|c|c|c|}
\hline Location & Cancellous & Demineralized & Cancellous & Demineralized \\
\hline & \multicolumn{2}{|c|}{ Mean Change \pm sd in $\mathrm{mm}$} & \multicolumn{2}{|c|}{ Range in $\mathrm{mm}$} \\
\hline Mid-Buccal & $0.6 \pm 2.3$ & $-0.8 \pm 0.8^{*}$ & -2.0 to 7.0 & -2.0 to 1.0 \\
\hline Mid-Lingual & $0.0 \pm 0.9$ & $-0.7 \pm 1.1^{*}$ & -1.0 to 2.0 & -2.5 to 1.5 \\
\hline Mesial & $-0.4 \pm 1.0$ & $-0.9 \pm 0.9^{*}$ & -1.7 to 1.8 & -2.0 to 0.3 \\
\hline Distal & $-0.6 \pm 0.6^{*}$ & $-0.9 \pm 0.7^{*}$ & -1.7 to 0.5 & -2.3 to 0.8 \\
\hline
\end{tabular}

$*=p<0.05$ between initial and 4-month values 
Table 19

CEJ to Osseous Crest Change at Adjacent Teeth

Mean \pm sd in $\mathbf{m m}$

\begin{tabular}{|lllll|}
\hline & $\mathbf{n}$ & Initial & Final & Change \\
\hline Cancellous & 12 & $3.0 \pm 0.7$ & $3.0 \pm 0.7$ & $0.0 \pm 0.5$ \\
Mesial & 12 & $3.0 \pm 0.7$ & $2.7 \pm 0.5$ & $0.3 \pm 0.5$ \\
\hline Distal & 12 & $3.1 \pm 0.6$ & $3.5 \pm 1.3$ & $-0.4 \pm 1.4$ \\
Memineralized & 12 & $3.0 \pm 0.5$ & $3.8 \pm 1.4$ & $-0.8 \pm 1.2$ \\
Distal & & & & \\
\hline
\end{tabular}


Table 20

Histologic Data at Implacement for Cancellous and Demineralized Sites

Mean \pm sd

\begin{tabular}{|lllccc|}
\hline Group & Time & n & \% Vital & \% Non-vital & \% Trabecular \\
\hline Cancellous & 4 month & 12 & $38 \pm 14$ & $29 \pm 14$ & $32 \pm 10$ \\
\hline Demineralized & 4 month & 12 & $40 \pm 13$ & $21 \pm 14$ & $39 \pm 11$ \\
\hline
\end{tabular}


Table 21

Comparison of Histologic Data from U of L Ridge Preservation Studies

Mean \pm sd

\begin{tabular}{|c|c|c|c|c|c|c|}
\hline Study & Treatment & $\begin{array}{l}\text { Time } \\
\text { in mo }\end{array}$ & $\overline{\mathbf{n}}$ & $\begin{array}{c}\% \\
\text { Vital }\end{array}$ & $\begin{array}{c}\% \\
\text { Non-vital }\end{array}$ & $\begin{array}{c}\% \\
\text { Trabecular }\end{array}$ \\
\hline $\begin{array}{l}\text { Iasella et al. } \\
2003\end{array}$ & $\begin{array}{l}\text { FDBA/BioMend } \\
\text { Extraction Alone }\end{array}$ & $\begin{array}{l}4-6 \\
4-6\end{array}$ & 12 & $\begin{array}{l}28 \pm 14 \\
54 \pm 12\end{array}$ & $37 \pm 18$ & $\begin{array}{l}35 \pm 10 \\
44 \pm 12\end{array}$ \\
\hline $\begin{array}{l}\text { Vance et al } \\
2004\end{array}$ & $\begin{array}{l}\text { Calmatrix } \\
\text { BioOss }\end{array}$ & $4 \mathrm{mo}$ & 12 & $61 \pm 9$ & $3 \pm 3$ & $\begin{array}{c}36 \pm 8 \\
59 \pm 16\end{array}$ \\
\hline $\begin{array}{l}\text { Adams et al } \\
2005\end{array}$ & $\begin{array}{l}\text { Intra } \\
\text { Cort/ADM } \\
\text { Overlay }\end{array}$ & 4 mo & 13 & $37 \pm 15$ & $31 \pm 15$ & $32 \pm 5$ \\
\hline $\begin{array}{l}\text { Siu et al } \\
2007\end{array}$ & $\begin{array}{l}\text { Flap } \\
\text { GMP/MnOs } \\
\text { Flapless }\end{array}$ & $\begin{array}{l}4 \mathrm{mo} \\
4 \mathrm{mo}\end{array}$ & $\begin{array}{l}12 \\
12\end{array}$ & $\begin{array}{l}35 \pm 15 \\
44 \pm 10\end{array}$ & $19 \pm 12$ & $46 \pm 17$ \\
\hline $\begin{array}{l}\text { Witonsky et al } \\
2009\end{array}$ & $\begin{array}{l}\text { CancBioOss/CP } \\
\text { Cort/PTFE }\end{array}$ & $\begin{array}{l}4 \mathrm{mo} \\
4 \mathrm{mo}\end{array}$ & 12 & $28 \pm 20$ & $37 \pm 16$ & $\begin{array}{l}35 \pm 13 \\
34 \pm 10\end{array}$ \\
\hline $\begin{array}{l}\text { Sams et al } \\
2010\end{array}$ & $\begin{array}{l}\text { Cancellous } \\
\text { Cortical }\end{array}$ & $4 \mathrm{mo}$ & $\begin{array}{l}12 \\
12\end{array}$ & $\begin{array}{l}37 \pm 13+ \\
19 \pm 10\end{array}$ & $\begin{array}{l}21 \pm 13+ \\
38 \pm 11\end{array}$ & $43 \pm 6$ \\
\hline $\begin{array}{l}\text { Kotevska et al } \\
2011\end{array}$ & $\begin{array}{l}\text { Cancellous } \\
\text { Demineralized }\end{array}$ & $4 \mathrm{mo}$ & 12 & $38 \pm 14$ & $29 \pm 14$ & $32 \pm 10$ \\
\hline
\end{tabular}


Table 22

Comparison of Histologic Data from U of L Ridge Augmentation Studies

Mean $\pm s d$

\begin{tabular}{|c|c|c|c|c|c|c|}
\hline Study & Treatment & $\begin{array}{l}\text { Time } \\
\text { in mo }\end{array}$ & $\mathbf{n}$ & $\begin{array}{c}\% \\
\text { Vital }\end{array}$ & $\begin{array}{c}\% \\
\text { Non-vital }\end{array}$ & $\begin{array}{c}\% \\
\text { Trabecular }\end{array}$ \\
\hline & Canc Block & 4 & 8 & $33 \pm 25$ & $24 \pm 18$ & $42 \pm 12$ \\
\hline $\begin{array}{l}\text { Cordini et al. } \\
2005\end{array}$ & $\begin{array}{l}\text { ADM membrane } \\
\text { DBM (Graf Flex) }\end{array}$ & 4 & 2 & $56 \pm 9$ & $5 \pm 5$ & $38 \pm 3$ \\
\hline & Canc Block & 4 & 11 & $51 \pm 18$ & $11 \pm 9$ & $39 \pm 14$ \\
\hline $\begin{array}{l}\text { Lahey et al. } \\
2005\end{array}$ & $\begin{array}{l}\text { ADM membrane } \\
\text { Particulate Cort }\end{array}$ & 4 & 10 & $58 \pm 12$ & $11 \pm 7$ & $31 \pm 7$ \\
\hline & & 4 & 11 & $56 \pm 12$ & $8 \pm 6$ & $36 \pm 10$ \\
\hline $\begin{array}{l}\text { Clagett et al. } \\
2006\end{array}$ & $\begin{array}{l}\text { ADM membrane } \\
\text { Paste (Regen) }\end{array}$ & 4 & 10 & $53 \pm 10$ & $8 \pm 8$ & $36 \pm 13$ \\
\hline & Canc Block & 4 & 11 & $57 \pm 10$ & $11 \pm 10$ & $32 \pm 10$ \\
\hline $\begin{array}{l}\text { Dib et al. } \\
2007\end{array}$ & $\begin{array}{l}\text { ADM membrane } \\
\text { GMP/MnOss }\end{array}$ & 4 & 12 & $60 \pm 13$ & $7 \pm 9$ & $33 \pm 11$ \\
\hline & Cortical & 4 & 11 & $47 \pm 11$ & $4 \pm 4$ & $49 \pm 9$ \\
\hline $\begin{array}{l}\text { Ratliff et al. } \\
2009\end{array}$ & $\begin{array}{l}\text { ADM membrane } \\
\text { Cancellous }\end{array}$ & 4 & 11 & $58 \pm 11+$ & $5 \pm 6$ & $37 \pm 8$ \\
\hline
\end{tabular}




\section{CHAPTER IV}

\section{DISCUSSION}

In this 4-month randomized, controlled, blinded clinical study of intrasocket ridge preservation in humans two different particulate allografts were compared. The positive control group received a cancellous allograft (Cancellous group) while the test group received a demineralized cortical allograft (Demineralized group). A PTFE barrier membrane was used for both groups. In terms of clinical ridge dimensions there were no significant differences between groups $(\mathrm{p}>0.05)$. Histologic evaluation of trephine cores also revealed no significant differences between the groups for vital bone, nonvital bone, or trabecular space $(\mathrm{p}>0.05)$.

The horizontal clinical ridge dimension results in this study are within the range reported in previous studies, which varies from -3.5 to $+1.1 \mathrm{~mm}$ (Table 8 ). The mean horizontal loss reported from those studies was $2.0 \pm 1.1 \mathrm{~mm}$. In this study, the Demineralized group lost $2.4 \pm 1.7 \mathrm{~mm}$ while the Cancellous group lost $1.3 \pm 1.4 \mathrm{~mm}$.

Previous reports of extraction alone showed a mean horizontal loss of $3.7 \pm 1.7$ $\mathrm{mm}$ or $43 \pm 17 \%$ of the initial ridge width (Table 6). In contrast, previous ridge preservation studies show a mean percent horizontal loss of $12 \pm 16 \%$ (Table 9). Thus, based on previous literature, the use of a ridge preservation procedure appears to be 
beneficial in terms of reducing the loss of ridge width. In this study the Demineralized group lost $26 \%$ of the crestal width while the Cancellous group lost only $15 \%$ ( $p>0.05$ ).

In this study, the vertical ridge dimension showed a mean mid-buccal change of +0.6 for the Cancellous group and $-0.8 \mathrm{~mm}$ for the Demineralized group $(\mathrm{p}>0.05)$. Previous studies have shown a mean change of $-0.1 \mathrm{~mm}$ with a range of -1.4 to $+1.3 \mathrm{~mm}$. Thus mean vertical change found in this study is comparable to the previous reports.

Histologic results from this study showed $38 \pm 14 \%$ vital bone, $29 \pm 14 \%$ nonvital bone and $32 \pm 10 \%$ trabecular space for the Cancellous group. The Demineralized group had $40 \pm 13 \%$ vtial, $21 \pm 14 \%$ nonvital and $39 \pm 11 \%$ trabecular space. Both treatments were effective in producing similar amounts of vital bone and there were no statistically significant difference between groups.

Previous studies of demineralized freeze-dried bone allograft (DFDBA) used in ridge preservation procedures have reported conflicting results regarding the production of vital bone. Becker et al (1998) reported that DFDBA biopsies primarily revealed nonvital bone particles entrapped within fibrous tissue with no evidence of either osteoblastic or osteoclastic activity. This finding suggests that DFDBA that minimal amounts of vital bone are formed. (Becker et al. 1994, 1996, 1998). In contrast, other studies have reported that residual DFDBA particles are surrounded by intimately apposed woven and lamellar bone with distinct cement lines and a lack of fibrous encapsulation. Osteoblasts lined endosteal spaces and new bone marrow exhibited a mild degree of fibrosis without signs of an inflammatory reaction (Brugnami et al. 1996, 1999, Smukler et al. 1999). In this study, the demineralized group healed with high percentage of vital bone, which was similar to the amount achieved by the cancellous group. The time of bone harvest for 
histologic examination varied in the previous studies, which may account for the differences or there may have been a qualitative difference in the graft itself. Irrespective of the reason for the conflict, the standardized 4-month time used for harvest in this study appears to afford an adequate period for new bone formation. This allows the implant to be placed in a site with a relatively high percentage of vital bone.

Despite the lack of statistical significance in ridge dimensions found in this study there was a strong trend towards better horizontal ( -15 vs. $-26 \%)$ and vertical $(+3$ vs. $7 \%$ ) results when the mineralized allograft was used. From this standpoint, the mineralized graft may afford some advantages although the variability in the result prevented the difference from reaching statistical significance. Histologically both grafts produced similar results. Both grafts produced an acceptable clinical and histologic result and both are appropriate for use in ridge preservation procedures. 


\section{CHAPTER V}

\section{CONCLUSIONS}

Within the limits of this study design and sample size it may be concluded that:

1) Mean crestal ridge width was preserved for both the Cancellous and Demineralized groups and there were no statistically significant differences between groups ( $p>$ $0.05)$.

2) There were no statistically significant differences in mid-buccal ridge height between groups $(p>0.05)$.

3) Histomorphometric analysis revealed that there were no significant differences in precent of vital bone, nonvital bone or trabecular space between groups ( $p>$ $0.05)$. 


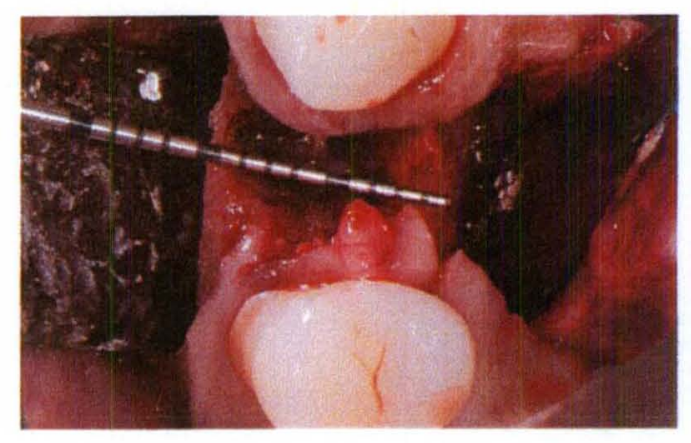

Figure 2. a) Case 1, Pre-op

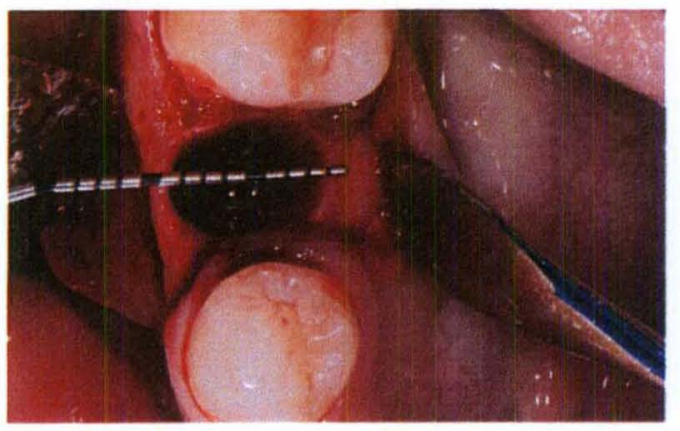

Figure 3. a) Case 2, Pre-op

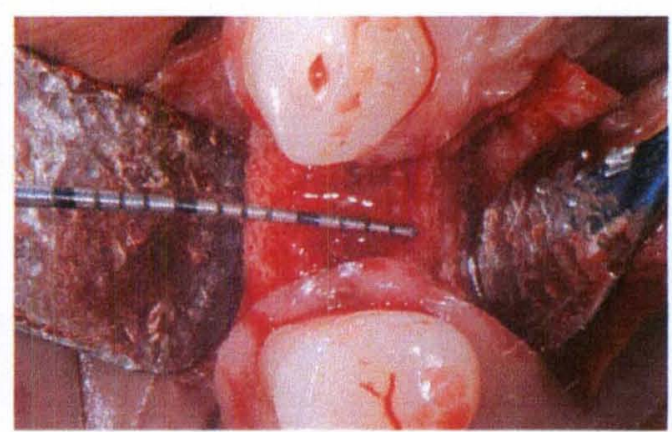

b) 4-month re-entry

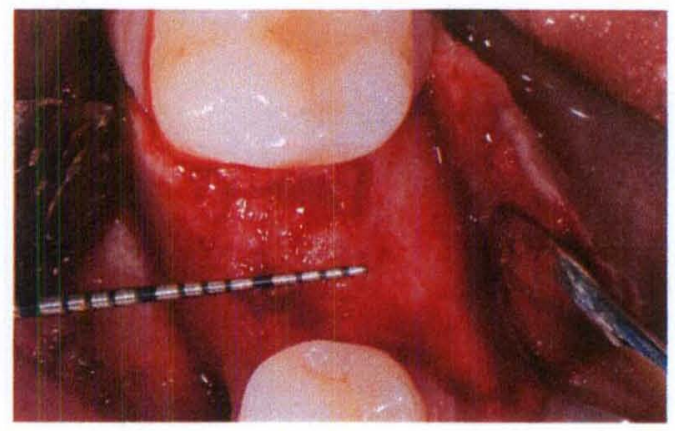

b) 4-month re-entry.

\section{Cancellous Allograft Group}




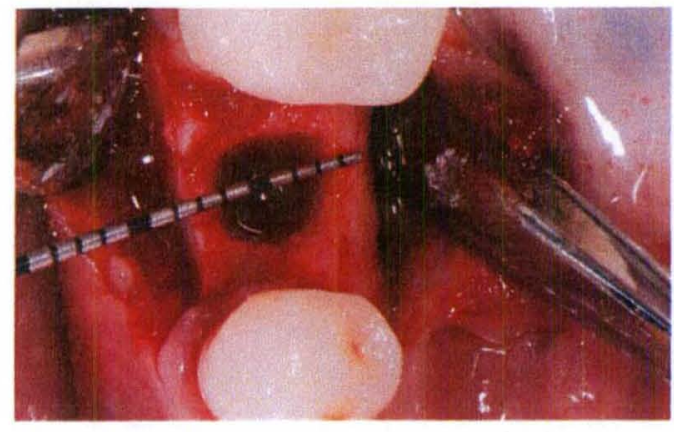

Figure 4. a) Case 3 Pre-op

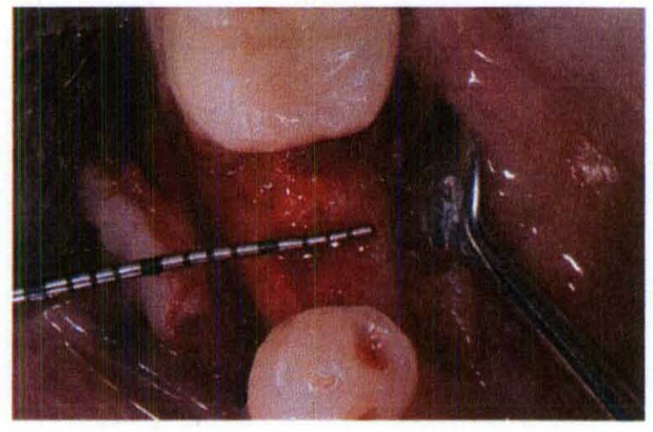

b) 4-month re-entry

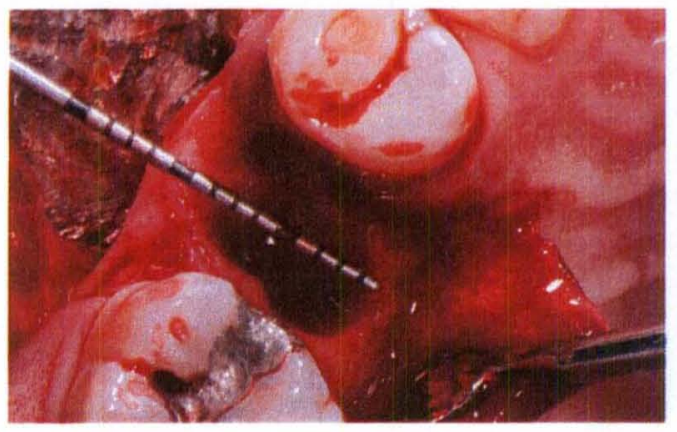

Figure 5. a) Case 4 Pre-op

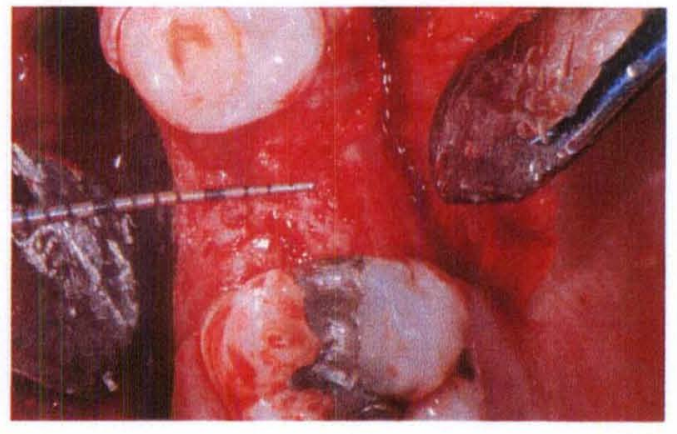

b) 4-month re-entry

\section{Demineralized Allograft Group}




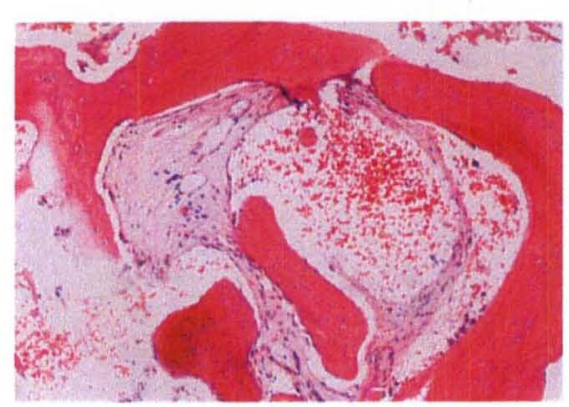

Figure 6. a) Cancellous vital bone

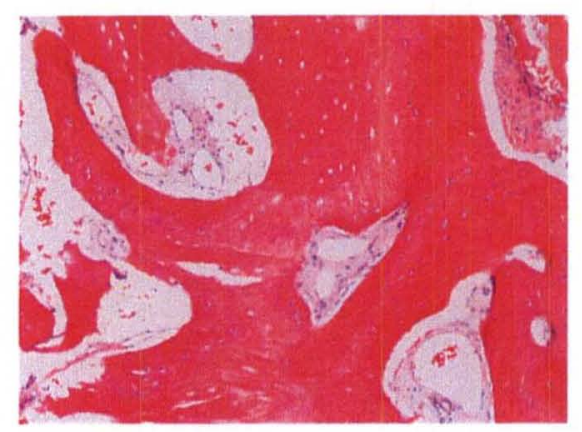

Figure 7. a) DFDBA vital \& vascular

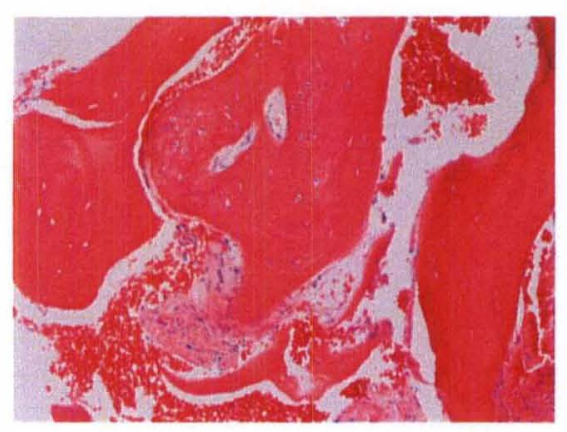

b) Cancellous vital \& nonvital bone

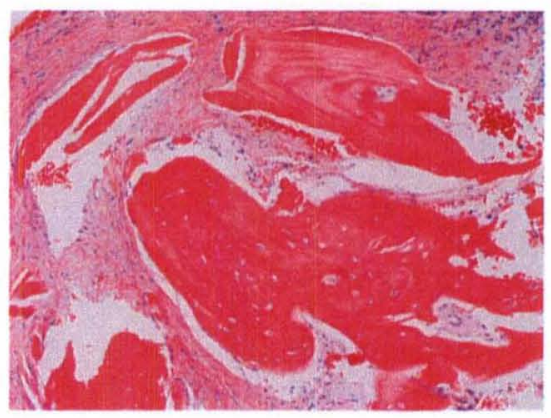

b) DFDBA vital \& nonvital

\section{Representative Histologic Sections}




\section{REFERENCES}

Adams DA. Ridge preservation comparing an intrasocket FDBA allograft alone to a combined intra-and extra-socket FDBA allograft both covered with acellular dermal matrix membrane. [Thesis]. Louisville, Kentucky. University of Louisville. 2005.

Amler MH, Johnson PL, Salaman I. Histologic and histochemical investigation of human alveolar socket healing in undisturbed extraction wounds. J Am Dent Assoc 1960;6:132144.

Araújo M, Linder E, Wennström J, Lindhe J. The influence of Bio-Oss Collagen on healing of an extraction socket: an experimental study in the dog. Int J Periodontics Restorative Dent 2008;28 (2):123-135.

Araujo MG, Lindhe J. Dimensional ridge alterations following tooth extraction. An experimental study in the dog. J Clin Periodontol 2005;32(2):212-218.

Araújo MG, Lindhe J. Ridge alterations following tooth extraction with and without flap elevation: an experimental study in the dog. Clin Oral Implants Res 2009:20(6):545-549.

Araujo MG, Lindhe J. Socket grafting with the use of autologous bone: an experimental study in the dog Clinical Oral Implant Research 2011;22:9-13

Araujo MG, Sukekava F, Wennstrom JL, Lindhe J. Ridge alterations following implant placement in fresh extraction sockets: an experimental study in the dog. J Clin Periodontol 2005;32(6):645-652

Artzi Z, Nemcovsky CE. The application of deproteinized bovine bone mineral for ridge preservation prior to implantation. Clinical and histological observations in a case report. J Periodontol 1998;69(9):1062-1067.

Artzi Z, Tal H, Dayan D. Porous bovine bone mineral in healing of human extraction sockets: Part 1: histomorphometric evaluations at 9 months. J Periodontol 2000;71(6):1015-1023. 
Artzi Z, Tal H, Dayan D. Pourous bovine bone mineral in healing of human extraction sockets: 2. Histochemical observations at 9 months. J Periodontol 2001:72(2):152-159.

Ash MM. Wheeler's dental anatomy, physiology, and occlusion (6th edition), WB Saunders Co., Philadelphia. Book 1984.

Ashman A. Postextraction ridge preservation using a synthetic alloplast. Implant Dent 2000;9(2):168-176.

Barone A, Aldini NN, Fini M, Giardino R, Guirado JL, Covani U. Xenograft versus extraction alone for ridge preservation after tooth removal: $A$ clinical and histomorphometric study. J Periodontol 2008;79:1370-1377.

Beck TM, Mealey BL. Histologic analysis of healing after tooth extraction with ridge preservation using mineralized human bone allograft J Periodontol 2010; 81:17651772

Becker W, Becker BE, Caffesse R. A comparison of demineralized freeze-dried bone and autologous bone to induce bone formation in human extraction sockets. J Periodontol 1994;65(12):1128-1133.

Becker W, Clokie C, Sennerby L, Urist MR, Becker BE. Histologic findings after implantation and evaluation of different grafting materials and titanium micro screws into extraction sockets. Case reports. J Periodontol 1998;69(4):414-421.

Becker W, Urist M, Becker BE, Jackson W, Parry DA, Bartold M, Vincenzzi G, De Georges D, Niederwanger M. Clinical and histologic observations of sites implanted with intraoral autologous bone grafts or allografts. 15 human case reports. J Periodontol 1996;67(10):1025-1033.

Berglundh T, Lindhe J, Jonsson K, Ericsson I. The topography of the vascular systems in the periodontal and peri-implant tissues in the dog. J Clin Periodontol 1994;21(3):189193.

Botticelli D, Berglundh T, Lindhe J. Resolution of bone defects of varying dimension and configuration in the marginal portion of the peri-implant bone. An experimental study in the dog. J Clin Periodontol 2004;31(4):309-317.

Botticelli D, Berglundh T, Persson LG, Lindhe J. Bone regeneration at implants with turned or rough surfaces in self-contained defects. An experimental study in the dog. J Clin Periodontol 2005;32(5):448-455. 
Boyne PJ. Osseous repair of the postextraction alveolus in man. Oral Surg Oral Med Oral Pathol 1966;21(6):805-813.

Brkovic BM, Prasad HS, Konandreas G, Milan R, Antunovic D, Sandor GK, Rohrer MD. Simple preservation of a maxillary extraction socket using beta-tricalcium phosphate with type I: Preliminary clinical and histomorphometric observations. J Can Dent Assoc 2008;74(6):523-528.

Brugnami F, Then PR, Moroi H, Kabani S, Leone CW. GBR in human extraction sockets and ridge defects prior to implant placement: Clinical results and histologic evidence of osteoblastic and osteoclastic activities in DFDBA. Int J Periodontics Restorative Dent 1999;19(3):259-268.

Brugnami F, Then PR, Moroi H, Leone CW. Histologic evaluation of human extraction sockets treated with demineralized freeze-dried bone allograft (DFDBA) and cell occlusive membrane. J Periodontol 1996;67(7):821-825.

Burchardt H. The biology of bone graft repair. Clin Orthop Relat Res 1983;174:28-42.

Camargo PM, Lekovic V, Weinlaender M, Klokkevold PR, Kenney EB, Dimitrijevic B, Nedic M, Jancovic S, Orsini M. Influence of bioactive glass on changes in alveolar process dimensions after exodontia. Oral Surg Oral Med Oral Pathol Oral Radiol Endod 2000;90(5):581-586.

Cardaropoli D, Cardaropoli G. Preservation of the postextraction alveolar ridge: A clinical and histologic study. J Periodont Res 2008;28:469-477.

Cardaropoli G, Araujo M, Lindhe J. Dynamics of bone tissue formation in tooth extraction sites. An experimental study in dogs. J Clin Periodontol 2003;30(9):809-818.

Cardaropoli G, Araujo MG, Hayacibara R, Sukekava F, Lindhe J. Healing of extraction sockets and surgically produced - augmented and non-sugmented - defects in the alveolar ridge. An experimental study in the dog. J Clin Periodontol 2005;32(5):435-440.

Carmagnola D, Berglundh T, Araujo M, Albrektsson T, Lindhe J. Bone healing around implants placed in a jaw defect augmented with Bio-Oss. An experimental study in dogs. J Clin Peridontol 2000;27(11):799-805.

Clafin R. Healing of disturbed and undisturbed extraction sites. J Am Dent Assoc 1936;23(6):945-959.

Clagett DR. Ridge augmentation comparing a cancellous block allograft to a moldable allograft paster using an acellular dermal matrix barrier membrane: A clinical and 
histologic study in humans. [Thesis]. 2006. Louisville, Kentucky. University of Louisville.

Cordini F. Ridge augmentation comparing cancellous block allograft to demineralized bone matrix and utilizing an acellular dermal matrix as a barrier membrane. [Thesis]. 2004. Louisville, Kentucky. University of Louisville.

Crespi R, Capparè $\mathrm{P}$, Gherlone E. Magnesium-enriched hydroxyapatite compared to calcium sulfate in the healing of human extraction sockets: radiographic and histomorphometric evaluation at 3 months. J Periodontol 2009;80(2):210-218.

Dib Z. Ridge augmentation comparing a cancellous block allograft to a demineralized bone matrix plug plus mineralized particulate allograft covered with an acellular dermal matrix barrier. [Thesis]. 2007. Louisville, Kentucky. University of Louisville.

Evian C, Rosenberg E, Coslet J, Corn H. The osteogenic activity of bone removed from healing extraction sockets in humans. J Periodontol 1982;53(2):81-85.

Fotek PD, Neiva RF, Wang HL. Comparison of dermal matrix and polytetrafluoroethylene membrane for socket bone augmentation: a clinical and histologic study. J Periodontol 2009;80(5):776-785.

Froum S, Cho S, Rosenberg E, Rohrer M, Tarnow D. Histologic comparison of healing extraction sockets implanted with bioactive glass or demineralized freeze-dried bone allograft: A pilot study. J Periodontol 2002;73(1):94-102.

Froum S, Cho SC, Elian N, Rosenberg E, Rohrer M, Tarnow D. Extraction sockets and implantation of hydroxyapatites with membrane barriers a histologic study. Implant Dent 2004;13(2): 153-161.

Garg AK. Alveolar ridge preservation during and after surgical tooth removal. Dent Implantol Update 2001;11(8):57-62.

Goldberg VM, Stevenson S. The biology of bone grafts. Semin Arthroplasty $1993 ; 4(2): 58-63$.

Guarnieri R, Pecora G, Fini M, Nicoli Aldini N, Giardino R, Orsini G, Piattelli A. Medical grade calcium sulfate hemihydrate in healing of human extraction sockets: Clinical and histological observations at 3 months. J Periodontol 2004;75(5):902-908.

Heberer S, Al-Chawaf B, Jablonski C, Nelson JJ, Lage H, Nelson K. Healing of ungrafted and grafted extraction sockets after 12 weeks: a prospective clinical study Int $\mathrm{J}$ Oral Maxillofac Implants 2011;26:385-392 
Horowitz RA. Extraction environment enhancement: Critical evaluation of early socket healing in long-term barrier protected extraction sockets. Compend Contin Educ Dent 2005;26(10):703-713.

Iasella JM, Greenwell H, Miller RL, Hill M, Drisko C, Bohra AA, Scheetz JP. Ridge preservation with freeze dried bone allograft and a collagen membrane compared to extraction alone for implant site development: A clinical and histologic study in humans. J Periodontol 2003;74(7):988-997.

Lahey B. Ridge augmentation comparing cancellous block allograft to particulate freeze dried bone allograft utilizing an acellular dermal matrix barrier membrane. [Thesis]. 2005. Louisville, Kentucky. University of Louisville.

Lekholm U, Zarb GA. Patient selection and preparation. In Branemark P-I, Zarb GA, Albrektsson T, editors: Tissue integrated prostheses: osseointegration in clinical dentistry. Chicago: Qunitessence. Book 1985;199-209.

Lekovic V, Camargo PM, Klokkevold PR, Weinlaender M, Kenney EB, Dimitrijevic B, Nedic M. Preservation of alveolar bone in extraction sockets using bioabsorbable membranes. J Periodontol. 1998;69(9):1044-1049.

Lekovic V, Kenney EB, Weinlaender M, Han T, Klokkevold P, Nedic M, Orsini M. A bone regenerative approach to alveolar ridge maintenance following tooth extraction. Report of 10 cases. J Periodontol 1997;68(6):563-570.

Loe $\mathrm{H}$. The gingival index, the plaque index and the retention index systems. J Periodontol 1967;38(Suppl):610-617.

Luczyszyn SM, Papalexiou V, Novaes AB Jr, Grisi MF, Souza SL, Taba M Jr. Acellular dermal matrix and hydroxyapatite in prevention of ridge deformities after tooth extraction. Implant Dent 2005;14(2):176-184.

MacNeill SR, Cobb CM, Rapley JW, Glaros AG, Spencer P. In vivo comparison of synthetic osseous graft materials. A preliminary study. J Clin Periodontol 1999;26(4):239-245.

Mangano C, Piatelli, A, Perrotti V, Iezzi G. Dense hydroxyapatitie inserted into postextraction sockets: A histologic and histomorphometric 20-year case report. J Periodontol 2008;79:929-933. 
McAllister BS, Haghighat K, Prasad HS, Roher MD. Histologic evaluation of recombinant human platelet-derived growth factor-BB after use in extraction socket defects: a case series J Periodont Restorative Dent 2010; 30:365-373

Mellonig J. Freeze-Dried bone allografts in periodontal reconstructive surgery. Dent Clin North Am 1991;35(3):505-520.

Mellonig J, Bowers G, Cotton W. Comparison of bone graft materials. Part II. New bone formation with autografts and allografts: A histological evaluation. J Periodontol 1981;52(6):297-302.

Neiva RF, Tsao YP, Eber R, Shotwell J, Billy E, Wang HL. Effects of a putty-form hydroxyapatite matrix combined with the synthetic cell-binding peptide $\mathrm{p}-15$ on alveolar ridge preservation. J Periodontol 2008;79:291-299.

Nemcovsky CE, Serfaty V. Alveolar ridge preservation following extraction of maxillary anterior teeth. Report on 23 consecutive cases. J Periodontol 1996;67(4):390-395.

Nevins ML, Camelo M, Schupbach P, Kim DM, Camelo JM, Nevins M. Human histologic evaluation of mineralized collagen bone substitute and recombinant plateletderived growth factor-BB to create bone for implant placement in extraction socket defects at 4 and 6 months: a case series. Int $\mathrm{J}$ Periodontics Restorative Dent 2009;29(2):129-139.

Pelegrine AA, Sorgi da Costa CE, Pizzigatti Correa ME, Comenalli Marques Jr JF. Clinical and histomorphometric evaluation of extraction sockets treated with an autologous bone marrow graft Clinical Oral Implant Research 2010;21:535-542

Pietrokovski J, Massler M. Alveolar ridge resorption following tooth extraction. J Prosth Dent 1967;17(1):21-27.

Ratliff MA. Ridge augmentation comparing a mineralized cancellous vs a cortical particluate allograft utilizing an acellular dermal matrix barrier membrane. [Thesis]. 2009. Louisville, Kentucky. University of Louisville.

Sams M. Ridge preservation comparing the clinical and histologic healing of a mineralized cortical vs. a mineralized cancellous allograft with an acellular dermal matrix barrier membrane. [Thesis]. 2010. Louisville, Kentucky. University of Louisville.

Schropp L, Wenzel A, Kostopoulos L, Karring T. Bone healing and soft tissue contour changes following single-tooth extraction: A clinical and radiographic 12 month prospective study. Int J Periodontics Restorative Dent 2003;23(4):313-323. 
Schwartz Z, Mellonig JT, Carnes DL Jr, De La Fontaine J, Cochran DL, Dean DD, Boyan BD. Ability of commercial demineralized freeze-dried bone allograft to induce new bone formation. J Periodontol 1996;67(9):918-926.

Schwartz Z, Somers A, Mellonig JT, Carnes DL, Dean DD, Cochran DL, Boyan BD. Ability of commercial demineralized freeze-dried bone allograft to induce new bone formation is dependent on donor age but not gender. J Periodontol 1998;69(4):470-478.

Schwartz Z, Weesner T, van Dijk S, Cochran DL, Mellonig JT, Lohmann CH, Carnes DL, Goldstein M, Dean DD, Boyan BD. Ability of deproteinized cancellous bovine bone to induce new bone formation. J Periodontol 2000;71(8):1258-1269.

Serino G, Biancu S, Iezzi G, Piatelli A. Ridge preservation following tooth extraction using a polylactide and polyglycolic sponge as space filler: a clinical and histological study in humans. Clin Oral Implants Res 2003;14(5):651-658.

Silness J, Löe H. Periodontal disease in pregnancy. II. Correlation between oral hygiene and periodontal conditions. Acta Odontol Scand 1964;22(1):121-135.

Simon BI, Von Hagen S, Deasy MJ, Faldu M, Resnansky D. Changes in alveolar bone height and width following ridge augmentation using bone graft and membranes. J Periodontol 2000;71(1):1774-1791.

Siu TL. Ridge preservation comparing a flap vs. flapless technique using a demineralized bone matrix allograft plus mineralized particulate allograft and covered with a calcium sulfate barrier. [Thesis]. Louisville, Kentucky. University of Louisville. 2007.

Smukler H, Landi L, Setayesh R. Histomorphometric evaluation of extraction sockets and deficient alveolar ridges treated with allograft and barrier membrane: A pilot study. Int $J$ Oral Maxillofac Implants 1999;14(3):407-416.

Tagge DL, O'Leary TJ, El-Kafrawy AH. The clinical and histological response of periodontal pockets to root planing and oral hygiene. J Periodontol 1975;46(9):527-533 .

Urist M. Bone: Formation by autoinduction. Science 1965;150(698):893-899.

Urist MR, Strates BS. Bone morphogenetic protein. J Dent Res 1971;50(9):1392-1406.

Vance GS, Greenwell H, Miller RL, Hill M, Johnston H, Scheetz JP. Comparison of an allograft in an experimental putty carrier and a bovine-derived xenograft used in ridge preservation: A clinical and histologic study in humans. Int J Oral Maxillofac Implants 2004;19(4):491-497. 
Wang HL, Sao JP. Histologic evaluation of socket augmentation with mineralized human allograft. Int J Periodontics Restorative Dent 2008;28(3):231-237.

Witonsky J. Ridge preservation comparing the clinical and histologic healing of a mineralized particulate allograft with a nonporous PTFE membrane vs. mineralized particulate xenograft with a collagen plug membrane. [Thesis]. 2009. Louisville, Kentucky. University of Louisville.

Woelfel JB. Dental Anatomy: Its Relevance to Dentistry. Fourth Edition . Philadelphia: Lea \& Febiger. Book 1990.

Yilmaz S, Efeoglu E, Kilic AR. Alveolar ridge reconstruction and/or preservation using root form bioglass cones. J Clin Periodontol 1998;25(10):832-839.

Zitzmann NU, Naef R, Scharer P. Resorbable versus nonresorbable membranes in combination with Bio-Oss for guided bone regeneration. Int $\mathrm{J}$ Oral Maxillofac Implants 1997;12(3):844-852.

Zitzmann NU, Scharer P, Marinello CP, Schupbach P, Berglundh T. Alveolar rdige augmentation with Bio-Oss: A histologic study in humans. Int J Periodontics Restorative Dent 2001;21(3):289-296.

Zubillaga G, Von Hagen S, Simon BI, Deasy MJ. Changes in alveolar bone height and width following post-extraction ridge augmentation using a fixed bioabsorbable membrane and demineralized freeze-drired bone osteoinducive graft. J Periodontol 2003;74(7):965-975. 


\section{Appendix A}

\section{The Plaque Index}

The plaque index of Silness and Loe (1964) was measured. Scores were as follows:

0 - No plaque

1 - A film of plaque adhering to the free gingival margin and adjacent area of the tooth.

The plaque may be seen in situ only after application of disclosing solution or by using the probe on the tooth surface.

2 - Moderate accumulation of soft deposits within the gingival pocket, or on the tooth and gingival margin, which can be seen with the naked eye.

3 - Abundance of soft matter within the gingival pocket and/or on the tooth and gingival margin.

Each gingival unit (buccal, lingual, mesiobuccal, distobuccal, mesiolingual, and distolingual) of the study tooth was given a score from 0-3, called the plaque index for the area. The scores from the 6 areas of the tooth were added and divided by 6 to give the plaque index for the tooth. 


\section{Appendix B}

\section{Gingival Index}

The gingival index of Loe (1967) was measured for the extracted tooth and any adjacent teeth. Scores were be recorded as follows:

$0=$ Normal gingiva.

$1=$ Mild inflammation - slight change in color slight edema, no bleeding on probing.

2 = Moderate inflammation - redness, edema, and glazing, bleeding on probing.

$3=$ Severe inflammation - marked redness and edema, ulceration and tendency to spontaneous bleeding.

Each gingival unit (mesiobuccal, buccal, distobuccal, distolingual, lingual, mesiolingual) of the tooth was given a score $0-3$. The scores for each unit were added together and divided by 6 to give the gingival index for that tooth. The score of the test tooth and the two adjacent teeth were added and divided by 3 to give the gingival index for the test of control sites. 


\section{Appendix C}

\section{Bleeding on Probing Index}

Tagge et al. (1975) reported on the use of an index of bleeding upon probing to show the amount of hemorrhage within the periodontal sulcus. The following is the index used to record bleeding on probing:

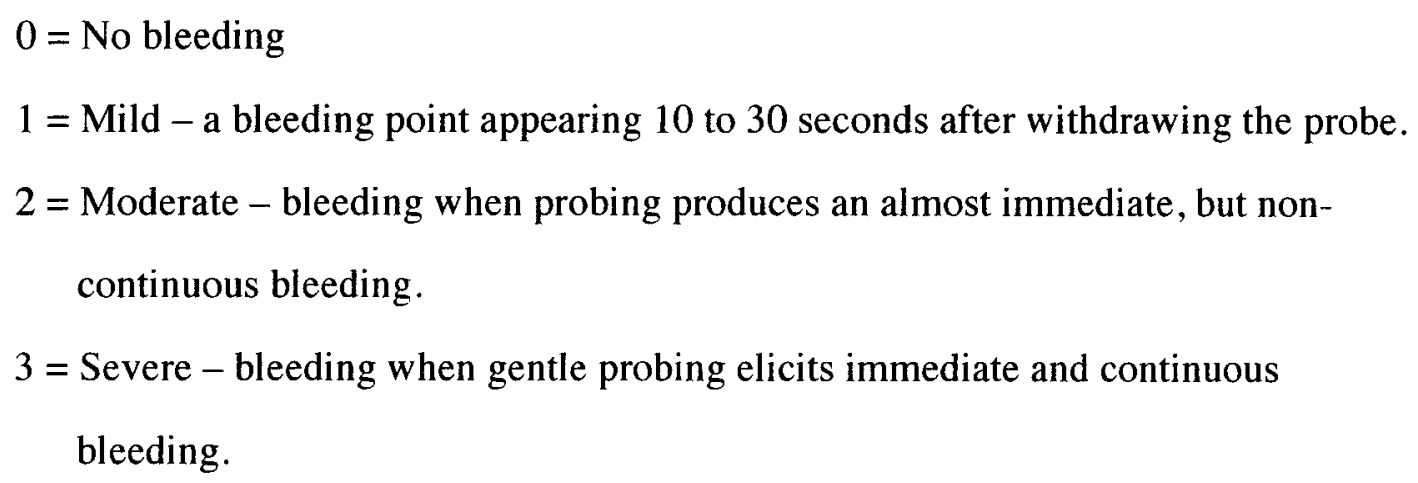




\section{Appendix D}

\section{Standardized Radiographic technique}

An occlusal stent was used to provide a stable foundation for the radiograph holder. A light cured resin material was placed on a Rinn radiograph holder and positioned to allow as near as possible paralleling technique. This material was light cured so that standardized radiographs can be compared. Radiographs were taken at baseline and 4 months. 


\section{Appendix E}

\section{$\underline{\text { Arithmetic determinations: }}$}

Ridge width (Post-extraction) $=$ A digital caliper was used to measure total mid-socket ridge width to the nearest $10^{-2} \mathrm{~mm}$ at the alveolar crest and $5 \mathrm{~mm}$ from the alveolar crest.

Ridge width (4 month re-entry) = Again, a digital caliper measured total ridge width to the nearest $10^{-2} \mathrm{~mm}$ at one point, mid socket, at the alveolar crest and $5 \mathrm{~mm}$ from the alveolar crest.

Change in alveolar crest height $=$ Initial: stent to alveolar crest minus re-entry stent to alveolar crest. 


\section{Appendix F}

\section{Stent fabrication}

Rigid stents were made of $3 \mathrm{~mm}$ thick light cured resin material in order to provide reproducible measurements. The tooth to be extracted was ground off the model and the light cured resin material was pressed over a cast. Three channels were prepared on the labial and three on the palato/lingual aspect of the stent in which a North Carolina periodontal probe was placed so that mesial, mid and distal measurements could be made on the labial and palato/lingual aspects of the crestal bone. Additionally, two channels were also prepared on the occlusal portion of the stent to provide measures of mesial and distal occlusal ridge height. Holes were prepared with a high-speed hand-piece. In this way, reproducible probing spots and directions of probe insertions were possible. 


\title{
CURRICULUM VITAE
}

\author{
Veneta Kotevska, DDS, MS
}

\section{EDUCATION}

2008-2011 University of Louisville Graduate Periodontics Certificate in Periodontics

2008-2011 University of Louisville

Master of Science in Oral Biology

2007 University of Colorado, School Dental Dentistry

Doctor Dental Surgery (D.D.S)

2004-2005 New York University, NY

AEGD (Advanced Education in General Dentistry)

\section{LICENSURE}

February 2008-Present Colorado Dental License

June 2009-Present Kentucky Dental License

Category II Laser certification 2009

DEA licensure granted 2008

ACLS certification 2009 


\section{PROFESSIONAL ASSOCIATIONS}

American Dental Association member

American Academy of Periodontology member

Academy of Osseointegration member

Kentucky Dental Association member

\section{EXTERNSHIPS}

Internal Medicine Rotation, University of Louisville Hospital, June 2009, 2010

Anesthesiology Rotation, University of Louisville Hospital, May 2009 